\title{
Description of five new species in the genus Phlyctinus Schoenherr (Coleoptera, Curculionidae): a first step in deciphering the $P$. callosus complex
}

\author{
Julien M. HARAN ${ }^{1,2, *}$, Steffan HANSEN ${ }^{2}$, Laure BENOIT ${ }^{3}$ \& Pia ADDISON ${ }^{4}$ \\ ${ }^{1,3}$ CBGP, CIRAD, Montpellier SupAgro, INRA, IRD, Montpellier University, Montpellier, France. \\ ${ }^{2,4}$ Department of Conservation Ecology and Entomology, Stellenbosch University, \\ Stellenbosch, South Africa. \\ *Corresponding author: julien.haran@cirad.fr \\ ${ }^{2}$ Email: shansen.rsa@gmail.com \\ ${ }^{3}$ Email: laure.benoit@cirad.fr \\ ${ }^{4}$ Email: pia@sun.ac.za \\ ${ }^{1}$ urn:1sid:zoobank.org:author:A04E1722-994A-44AD-8FD2-28DC0F220805 \\ ${ }^{2}$ urn:lsid:zoobank.org:author:52F0FC34-03F6-4F04-A1AA-FE7607B0EFBC \\ ${ }^{3}$ urn:1sid:zoobank.org:author:61963F74-724B-4174-9E9A-8817A3516B0E \\ ${ }^{4}$ urn:1sid:zoobank.org:author:A84CE8F2-E423-4ABF-815C-35169E6E42E5
}

\begin{abstract}
Phlyctinus callosus (Schoenherr, 1826) (Curculionidae, Entiminae, Oosomini) is a species native to the Western Cape province of the Republic of South Africa. It is regarded as a key pest of orchards and vineyards. Detailed observations of its morphology and ecology have shown this species to be a complex of closely related species. In this study we describe the species of this complex, provide morphological and molecular diagnostic tools to distinguish between species, and review their distribution and host plant associations. In all, six species are recognized in the $P$. callosus complex and five are described as new (P. grootbosensis Haran sp. nov., P. xerophilus Haran sp. nov., P. planithorax Haran sp. nov., P. littoralis Haran sp. nov., $P$. aloevorus Haran sp. nov.). Sequences of the mitochondrial gene used (cytochrome oxidase I, $C O I$ ) indicated that $P$. xerophilus Haran sp. nov. might comprise several cryptic species for which stable morphological features could not be identified at this stage. The species of the genus Phlyctinus appear to be primarily associated with various Asteraceae found in humid, sandy and disturbed habitats.
\end{abstract}

Keywords. Entiminae, Oosomini, species complex, Banded Fruit Weevil, Garden Weevil.

Haran J.M., Hansen S., Benoit L. \& Addison P. 2020. Description of five new species in the genus Phlyctinus Schoenherr (Coleoptera, Curculionidae): a first step in deciphering the P. callosus complex. European Journal of Taxonomy 669: 1-29. https://doi.org/10.5852/ejt.2020.669

\section{Introduction}

The Greater Cape Floristic Region in South Africa is a recognized biodiversity hotspot (Ellis et al. 2014). Plant diversity in this relatively small area reaches unusually high levels (Linder 2003; Hoffmann 
et al. 2015; Bouchenak-Khelladi \& Linder 2017). Botanical studies have dominated the research on biodiversity in this region, but studies focusing on the species diversity, plant associations and speciation processes of phytophagous insects associated with these plants remain in their infancy (Procheş \& Cowling 2006; Procheș et al. 2009). Weevils (Coleoptera, Curculionoidea) constitute a superdiverse beetle group that is still poorly known in this area. Taxonomic revisions over recent decades have demonstrated that research on this superfamily is still in the early 'Linnean phase', with less than $20 \%$ of the fauna described (Oberprieler et al. 2007). Weevils, however, can cause substantial damage to cultivated plants, and a large number of native species have shifted or extended their host plant range to introduced cultivated plants and have become pests in agriculture and forestry (Marshall 1927). For example, at least seven native weevils are regarded as pests in orchards and vineyards in the Western Cape province (Prinsloo \& Uys 2015).

Phlyctinus callosus (Schoenherr, 1826) (Curculionidae, Entiminae, Oosomini) is a broad-nosed weevil endemic to the Western Cape province of South Africa. It is regarded as a key pest on deciduous fruit and vines in that region (Pringle et al. 2015). The larvae feed on roots in the soil and are considered as polyphagous, having been reported from a large range of plant families including Asteraceae, Asparagaceae, Crassulaceae, Fabaceae, Plantaginaceae, Rosaceae and Vitaceae (Pringle et al. 2015). The adult weevils feed on the aerial parts of the plants, on which they cause damage by notching the leaves, fruits, blossoms and stems (Barnes 1989). Managing this pest is difficult because the species seemingly has no efficient biological control agents and because the larvae and adults are difficult to reach by conventional control methods (Pringle et al. 2015). Apart from direct crop losses, P. callosus is also an occasional phytosanitary pest that hitchhikes on exported fruit. It was first reported outside its native range of South Africa in 1869 on St Helena Island (Wollaston 1869), then in Australia, Ascension Island, New Zealand, Norfolk Island, the Kermadec Islands and more recently on the island of Reunion (Decelle \& Voss 1972; Alonso-Zarazaga \& Lyal 1999; Poussereau et al. 2013; Pullen et al. 2014). This species has also been detected (but is seemingly not established) in the northern hemisphere (Anonymous 1950; Myburgh \& Kriegler 1967; Brown 2004; Duff 2012), where it is considered as a potential invasive pest (Opatowski 2001). In this context it is critical to ascertain the taxonomic identity of the species.

The genus Phlyctinus was first described by Schoenherr (1826) as a subgenus of the genus Peritelus Germar, 1824 with Peritelus (Phlyctinus) callosus being its type species. The detailed nomenclatural trajectory of the genus Phlyctinus is beyond the scope of this study but can be summarized as follows: Schoenherr (1834) elevated Phlyctinus to generic rank and included six species in it, and later (Schoenherr 1843) added eight additional species to this genus. In total, 14 species were therefore placed in Phlyctinus, all from the Cape of Good Hope region of the current Republic of South Africa. All these species but $P$. callosus were later transferred to Oosomus Schoenherr, 1823 and Pyctoderes Schoenherr, 1823 (Entiminae, Oosomini), with these genera being well distinguished from it (Lacordaire 1854; Lona 1937; Marshall 1952). As a result, Phlyctinus is currently a monospecific genus, with P. callosus as the only valid species described in it, and this genus has not received any formal taxonomic treatment since Schoenherr (1843).

However, there have been some indications that $P$. callosus might constitute a complex of closely related species. Barnes \& Pringle (1988) first reported poor efficacy of insecticides on some populations of P. callosus in the Elgin Area of the Western Cape, but no difference in sensitivity to insecticides could be established under laboratory conditions between what they called 'strains'. More recently, Pringle et al. (2015) reported the unpredictable population dynamics of this weevil and the inconsistency of its host plants across regions and countries. In addition, a morphological study of the species showed that several features were variable across its distribution range, raising doubts as to its identity in different regions. 
In this study we used an integrative taxonomic approach to decipher the $P$. callosus species-complex. Traditional recognition of species based on morphology was combined with sequencing of the standard DNA Barcode fragment (COI). Five new species are described, and morphological and molecular diagnostic tools to distinguish between the species are provided. The distribution and host plant associations of the species are updated and the implication of this complex of species for pest management is discussed.

\section{Material and methods}

\section{Sampling}

Dry-mounted specimens were borrowed from collections housed in South African museums (Iziko South African Museum, Cape Town; Ditsong Museum, Pretoria; South African National Collection of Insects, Pretoria; Stellenbosch University Collection, Stellenbosch) and some European museums (Natural History Museum, London, United Kingdom; Swedish Museum of Natural History, Stockholm, Sweden). Fresh specimens of Phlyctinus were also sampled in agro-ecosystems and surrounding natural vegetation across South Africa, with a focus on the Western Cape province. Specimens were collected either by beating/sweeping the vegetation at night or by a visual search at the base of plants during the day. After collecting, specimens were stored in $96 \%$ ethanol at ambient temperature.

\section{Preparation and taxonomic treatment}

The abdomens of adult specimens were extracted and digested in $\mathrm{KOH}$ to obtain clean preparations of genital structures, as these are commonly used to distinguish between species in Entiminae (Borovec \& Skuhrovec 2018; Borovec 2019). The habitus and male genitalia were photographed using a Keyence ${ }^{\circledR}$ VHX5000 imaging system. Most morphological characters used to distinguish between species of Phlyctinus are found on the ventrites and the penis of the male, so these structures should be properly prepared for identification. The copulatory sclerite of the penis of the male is informative for species identification, but it is usually hidden by the teguments of the endophallus and should be dissected as well. This sclerite shows a complex structure, forming a ' $\mathrm{Y}$ ' in dorsal view. The two apical expansions, hereafter called 'arms', vary between species in terms of length, curvature and pilosity. The base of the ' $Y$ ', hereafter called the 'body', also varies in length and shape. Females of Phlyctinus show very few stable morphological differences between most species and cannot be used alone for identification. As knowledge stands, female terminalia (sternite VIII, spermatheca and gonocoxites) do not provide diagnostic characters either to distinguish between species. A description of these structures is provided for the species $P$. callosus only. Measurements were taken with an optical micrometer. Body length refers to the distance from the apical margin of the head (excluding the rostrum) to the apex of the elytra in dorsal view. Rostrum length refers to the distance between the anterior margin of the eyes and the apex of the rostrum. The width to length ratio (w/l) was measured at the widest point of the rostrum, prothorax, the elytra and the penis (body). The length of the elytra was measured between the anterior part of the scutellum and the apex of the elytra in dorsal view. The length of the penis was measured between the base and the apex of the penis body (apodemes excluded). The terminology used follows Lyal (2019). The identity of Phlyctinus callosus was established by comparison with type material and the original description. The designation of a lectotype for this species follows ICZN code article 74. All new species are authored by the first author of this article.

\section{Molecular analysis}

For each species, specimens were sequenced for the standard DNA Barcode region (Hebert et al. 2003) to support the interspecific differences identified from the morphological study (Table 1). DNA was extracted from whole specimens, or a leg, using a DNeasy Blood \& Tissue kit (Qiagen, Hilden, Germany). PCR amplification was carried out using a mix of primers for amplification of the standard Barcode region (mitochondrial cytochrome c oxidase subunit I, COI) of invertebrates (Appendix 1). 


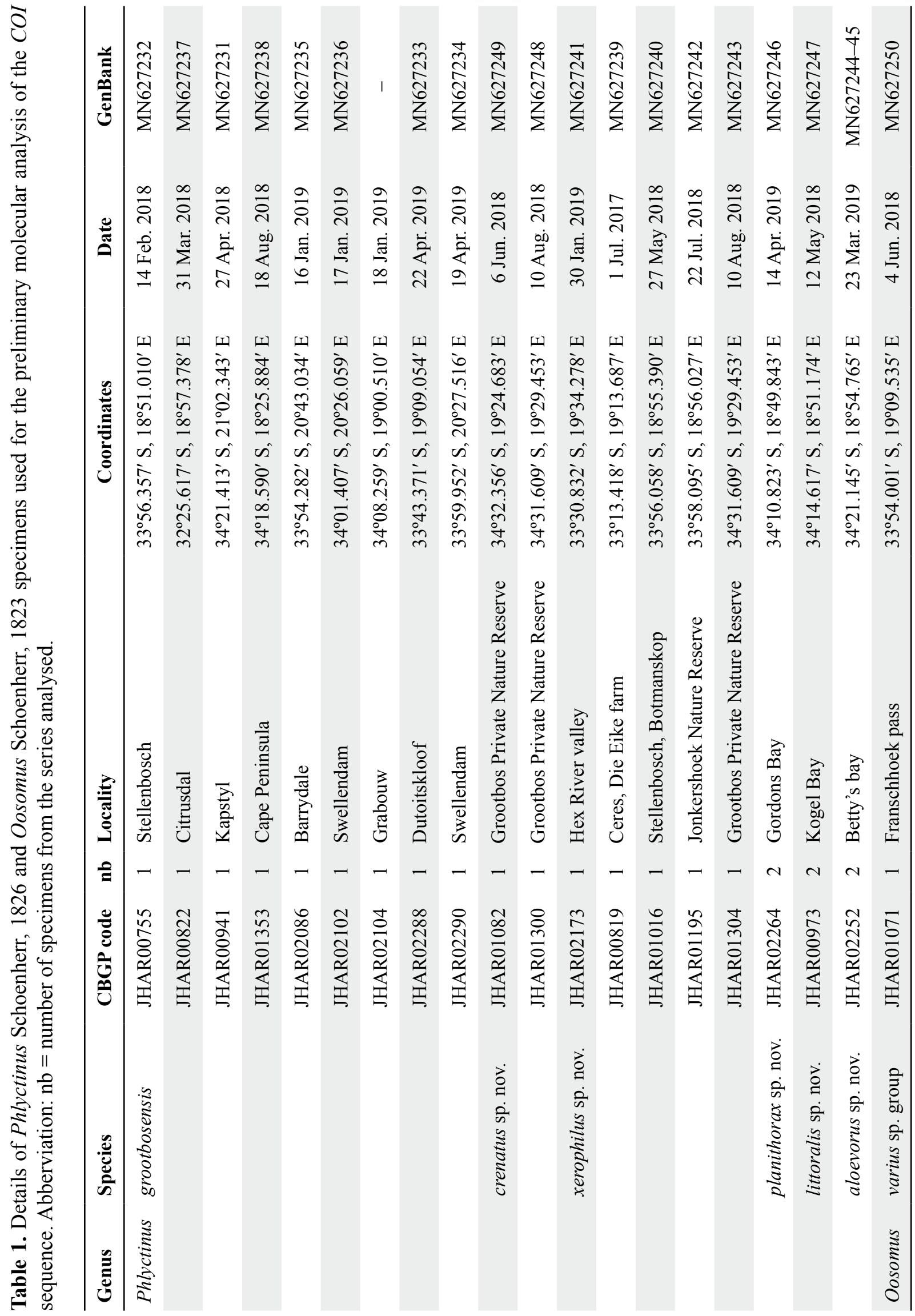


PCR reactions were carried out on a Mastercycler ${ }^{\circledR}$ Nexus (Eppendorf, Hamburg, Germany) in a final volume of $10 \mu \mathrm{L}$ containing $5 \mu \mathrm{l}$ of Multiplex PCR Master Mix (Qiagen, Hilden, Germany), $2 \mu \mathrm{M}$ of each primer and $2 \mu \mathrm{l}$ of DNA template. The PCR conditions were as follows: initial DNA denaturation at $94^{\circ} \mathrm{C}$ for 15 minutes, followed by 35 cycles of $30 \mathrm{~s}$ at $94^{\circ} \mathrm{C}, 1 \mathrm{~min}$ at $52^{\circ} \mathrm{C}$ and $1 \mathrm{~min}$ at $72^{\circ} \mathrm{C}$, with a final extension of $15 \mathrm{~min}$ at $72^{\circ} \mathrm{C}$. The PCR products were paired-end sequenced by Eurofins Genomics (http://www.eurofinsgenomics.eu/). All voucher specimens were mounted, dried and deposited at CBGP, Montpellier, France, in the CIRAD collection (https://doi.org/10.15454/D6XAKL) and at the Iziko South African Museum, Cape Town, South Africa. Barcode sequences were aligned and manually checked using CodonCode Aligner ver. 3.7.1 (CodonCode Corporation, Centerville, MA, USA) to verify the absence of pseudogenes using standard detection methods (Haran et al. 2015). Uncorrected p-distance values of pairwise genetic distances between species were computed with Mega 7 (Kumar et al. 2016). Preliminary reconstruction of interspecific phylogenetic relationships was carried out on COI sequences using PhyML (Guindon \& Gascuel 2003) with 1000 bootstrap replicates.

\section{Depositories}

$\mathrm{BMNH}=$ Natural History Museum, London, UK

CBGP $=$ Centre de Biologie pour la Gestion des Populations, Montpellier, France

$\mathrm{DMC}=$ Dominique Menet private collection, Longlaville, France

NHRS $=$ Swedish Museum of Natural History, Stockholm, Sweden

SAMC $=$ Iziko South African Museum, Cape Town, South Africa

SANC $=$ South African National Collection of Insects, Pretoria, South Africa

SUIC = Stellenbosch University Insect Collection, Stellenbosch, South Africa

TMSA = Ditsong National Museum of Natural History, Pretoria, South Africa (formerly Transvaal Museum)

\section{Results}

\section{Taxonomic account}

Order Coleoptera Linnaeus, 1758

Superfamily Curculionoidea Latreille, 1802

Family Curculionidae Latreille, 1802

Subfamily Entiminae Schoenherr, 1823

Tribe Oosomini Lacordaire, 1863

Genus Phlyctinus Schoenherr, 1826

Phlyctinus callosus (Schoenherr, 1826)

Figs 1A, 2A, 3A, 3E, 4A

Peritelus (Phlyctinus) callosus Schoenherr, 1826: 196.

Sciobius subnodosus Wollaston, 1869: 416.

Ocynoma rhysa Olliff, 1888: 1007

Rhyncogonus germanus Broun, 1893: 293

Phlyctinus callosus - Schoenherr 1834: 523; 1843: 160.

\section{Etymology}

The genus and species names were probably named after the callosities present on the apex of the elytra in adults. 


\section{Material examined}

Lectotype (here designated)

REPUBLIC OF SOUTH AFRICA • 1 đ; "Cap. b. spei. [Cape of Good Hope/South-West part of the Western Cape province of South Africa] Wakerman" "Phlyctinus callosus" "Typus" "NHRS JLKB000065427" "Lectotype [here designated] Phlyctinus callosus (Schoenherr 1826), Haran 2019"; NHRS JLKB000065427.

\section{Paralectotypes}

REPUBLIC OF SOUTH AFRICA • 1 \&; "Cap. b. spei. [Cape of Good Hope/South-West part of the Western Cape province of South Africa] Billb." "Paratypus" "NHRS JLKB000065429" "Paralectotype Phlyctinus callosus (Schoenherr 1826), Haran 2019”; NHRS JLKB000065429 • 1 क; "Cap. b. spei. [Cape of Good Hope/South-West part of the Western Cape province of South Africa] Mus. Billb." "Paratypus" "NHRS JLKB000065430" "Paralectotype Phlyctinus callosus (Schoenherr 1826), Haran 2019”; NHRS JLKB000065430.

The male paralectotype of this series (NHRS JLKB000065428) belongs to a different species, see the discussion section.

\section{Other material}

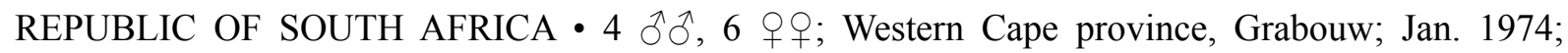
V.B. Whitehead leg.; "on apple"; SAMC SAM-COL-A064543 - 1 §; Riviersonderend; $34.03^{\circ} \mathrm{S}$,

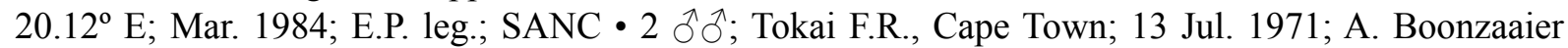
leg.; "on Pinus radiata"; Ac Ca 1002; SAMC SAM-COL-A064544 • 1 ô; Cape Town, Die Hellen;

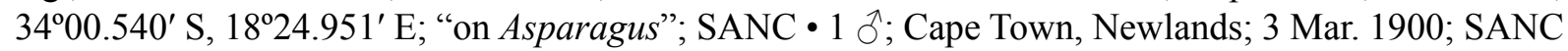
- 1 O̊; Camps Bay; 23 May 1975; V.R. Nort leg.; SANC • 2 q ; ; Devils Peak, Cape Town; 9 Nov. 1983; M. MacPherson leg.; SAMC SAM-COL-A064545 • 1 \%; Bredasdorp, Cape Peninsula; Phlyctinus callosus Boh. det. Marshall; SAMC SAM-COL-A045050 • 1 +; Pearly Beach, Bredasdorp; Sep. 1959; Phlyctinus callosus Boh. det. R. Oberprieler 1987; SAMC SAM-COL-A045051 • 1 q; Hout Bay; May 1935; A.J. Hesse leg.; SAMC SAM-COL-A045056 • 2 ô $\sigma^{\lambda}$; Orangekloof, Wynberg, Cape Peninsula; Mar. 1928; A.J. Hesse leg.; SAMC SAM-COL-A045058, A045064 • 2 o $\circ$; Cape Town; 1911; L.C. Péringuey leg.; Phlyctinus callosus Boh. det. R. Oberprieler 1987; SAMC SAM-COL-A045060 • 1 \%; Rondebosch;

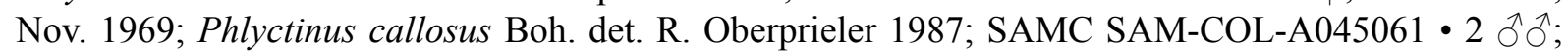
Somerset West; Aug. 1958; A.J. Hesse, det. as Phlyctinus callosus; SAMC SAM-COL-A045065 • 1 \%; Somerset West; Sep. 1958; A.J. Hesse, det. as Phlyctinus callosus; SAMC SAM-COL-A045066 • 1 ; ; Holub; det. as Phlyctinus callosus [A.J. Hesse's handwriting]; SAMC SAM-COL-A045067 • 1 万’; Table Mountain, Cape Town; Mar. 1920; det. as Phlyctinus callosus [A.J. Hesse's handwriting]; SAMC SAM-COL-A045071 • 2 specs; Cape Peninsula, Circular Drive; 18 Aug. 2018; J. Haran leg.; sweeping vegetation; CBGP code JHAR01353; CBGP • 7 specs; 20 km N of Citrusdal; 31 Mar. 2018; J. Haran leg.; by night on leaves of ornamental Gaziana sp.; CBGP code JHAR00822; CBGP 13 specs; Stellenbosch, train station; 14 Feb. 2018; J. Haran leg.; at base and on leaves of ornamental pelargonium; CBGP code JHAR00755; CBGP • 1 spec.; Vermaaklikheid, Kapstyl; 27 Apr. 2018; J. Haran leg.; on white wall;

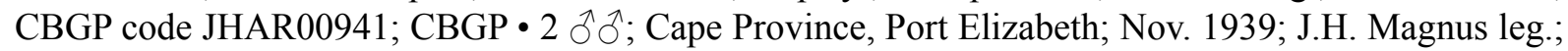

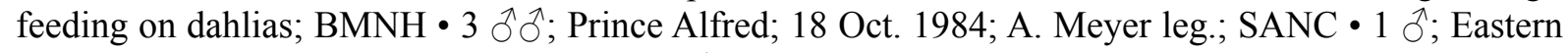
Cape, Port Elizabeth; '91.41'??; BMNH・1 ठ̊; Port Elizabeth; 1 Nov. 1939; J.H. leg.; SANC.

AUSTRALIA • 1 đ; Victoria, Laverton; 8 Oct. 1985; S.K. Smith leg.; BMNH • 1 ơ; N.S.W., Blackheath; Dec. 1928; E.C. Levitt leg.; "on Dahlia"; BMNH.

NEW ZEALAND • 1 đ̊; Silver Bert, Fixton; Apr. 1921; J.G. Myers leg.; "Phlyctinus callosus Boh. Det GAK Marshall”; BMNH • 1 §ో; Wanganui; 20 Apr. 1948; D.M. leg.; “on X. gerbera”; SANC. 
NORFOLK ISLAND • 1 đ̊; Ball Bay; 5 Apr. 1973; Mr and Mrs Jowett leg.; BMNH • 1 đ̊; same collection data as for preceding; May 1976; Mr and Mrs Jowett leg.; BMNH $\bullet 1$ §, 1 O; same collection data as for preceding; Nov. 1973; Mr and Mrs Jowett leg.; BMNH • 1 đ̊; same collection data as for preceding; alt. 300 ft.; 10 May 1939; I. McComish leg.; "on leaves of french bean"; BMNH.

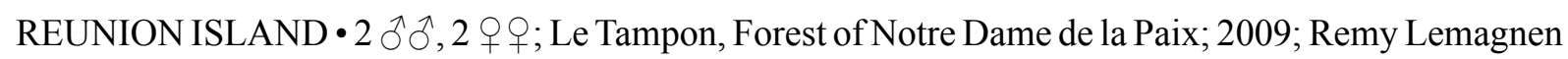
leg.; R186; DMC.

ST HELENA ISLAND • 1 $\widehat{\partial}$, lectotype of Sciobius subnodosus (here designated); "St Helena. 71/1378/12" "SYN-TYPE" "Otiorhynchus subnodosus W." "? Syntype Sciobius subnodosus Woll. Det. R.G. Booth 2014" "Lectotype Sciobius subnodosus Wollaston 1869. J. Haran des. 2019"; BMNH • 2 q ; same collection data as for preceding; "Paralectotypes Sciobius subnodosus Wollaston 1869. J. Haran des. 2019"; BMNH • 1 ð’; Diana's Peak; 27 Jun. 1959; C.R. Wallace leg.; "swept from grass"; BMNH • $1 \mathrm{o}^{\text {T}}$; Hutts Gate; 21 Jul. 1959; C.R. Wallace leg.; "on solanaceous weed"; BMNH.

USA • 1 \% ; California, Davis; $38.33^{\circ}$ N, $121.44^{\circ}$ W; 9 Jan. 1976; P. Willer leg.; "on imported olives"; SANC.

\section{Redescription}

Body LENGTH. 4.8-6.1 mm.

Colour. Body integument dark red, head and prothorax darker, usually black; vestiture of elytra consisting of a mixture of elongate scales, twice as long as wide, and smaller scales $4-5 \times$ as long as wide, not concealing integument; scales brown and/or pearly green or pearly brown, pale scales usually forming a transverse band on apical $2 / 3$ of elytra, longitudinal bands on basal half of sides of prothorax and a few dots on apical margin of prothorax.

HEAD. Rostrum longer than wide (w/1 ratio: 0.68$)$ in both sexes, at base $1.05 \times$ as wide as at apex, sides slightly concave near middle of length; epifrons as wide as width of one eye, narrower at base than distance between eyes, sides subparallel, upper face with a longitudinal carina extending from basal transverse groove to nasal plate, visible through scales; nasal plate V-shaped, reaching level of antennal insertion basally, bare of scales, with only minute setae inserted in scattered punctures and 3 pairs of long setae apically near insertion of mandibles ( 2 short and 1 very long); antennal scrobes slightly curved in lateral view, directed to middle of eye, separated from it by a strip of scales narrower than diameter of eyes; mandibles trisetose, bare of scales. Forehead with a short longitudinal furrow between eyes, scales and setae arranged centripetally towards a point below base of eyes. Eyes protruding, surface strongly conical in dorsal view. Antennae slender, scape $0.75 \times$ as long as funicle, slightly bisinuate, subclavate at apex, exceeding anterior margin of prothorax in repose; funicle with segments 1-2 elongate, 1 shorter $(0.65 \times)$ than 2 , segments $3-6$ longer than wide, conical, shortening apicad, segment 7 longer and slightly wider than 6; club spindle-shaped, segment 1 longer than 2, margins slightly sinuous.

Prothorax. Slightly wider than long (w/l ratio: 1.16), widest slightly before middle of length, apical margin $0.68 \times$ as wide as at base, sides rounded, apical half slightly concave; integument forming a dense cover of elongate granules orientated parallel to median carina and two slight depressions on each side of median carina; median carina raised, smooth and shiny, not reaching apical and basal margins of prothorax.

ELYTRA. Sides convex, widest before middle of length (w/l ratio: 0.76 in $\widehat{\partial}, 0.80$ in 9 ), integument weakly reticulate, shiny, interstriae raised, $2-4 \times$ as wide as width of striae in basal half; large declivital callosities present on apical $1 / 4$ of interstria 3, 5 and 7 and smaller ones on 2, 4, 6 and 8; each interstria with a series of semi-erect, elongate whitish scales, condensed on callosities. 

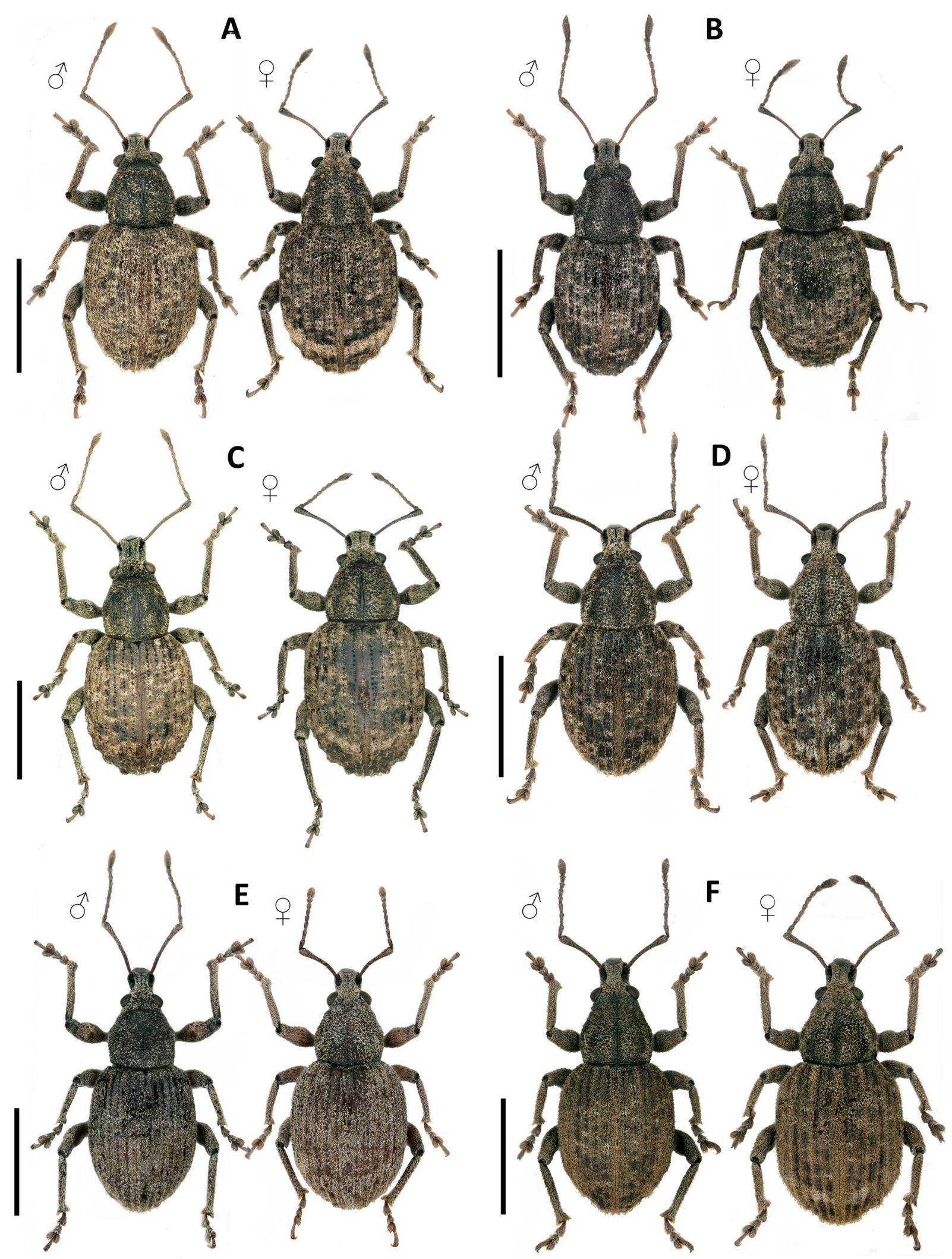
AвDOMEN. Underside with pearly green or pearly brown scales, not concealing integument, more condensed on metanepisterna; ventrite 1 as long as $2+3+4$, slightly convex in middle ( + ), or concave with erect setae as long as claws $(\hat{\delta})$, ventrite 5 slightly longer than $3+4$, with erect setae in middle and near apex and a small tubercle near apex ( $(+)$, or with a large cavity in apical $2 / 3$, with long erect setae condensed on margin of cavity, forming two brushes at apical and basal margins, and a longitudinal line

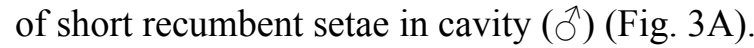

LEGS. Femora clavate, unarmed, with a ring of more condensed pale scales near middle; tibiae straight, unarmed, slightly bisinuate on ventral side, apical setal comb equal in length, golden; metatibial corbels absent; claws simple, free, equal in length.

Genitalia (male terminalia). Body of penis elongate, $0.7 \times$ as long as apodemes, sides convex, widest in basal $1 / 3$, converging towards apex and slightly narrowed before it (ratio w/l: 0.45 ), in lateral view curvature weak, mainly in basal half, and just before apex (Fig. 2A); copulatory sclerite with left arm as long as body, bearing setae at base, comb of right arm with setae parallel, right area of body wider than left area.

Female terminalia. Sternite VIII with plate subtriangular in dorsal view, apically sharply pointed, widest near basal $1 / 3$, in lateral view lanceolate, widest near middle of length, anterior margin well developed, glabrous, posterior margin ill-defined up to middle of length of plate; apodeme short, robust, as long as or slightly longer than length of plate; transverse bar moderately sclerotised. Gonocoxites long, flat, sides converging apicad, rounded at apex, with long apical styli $4 \times$ as long as wide, bearing long apical setae. Spermatheca with regularly wide curved cornu; ramus well developed, twice as long as collum, ramus and collum parallel; nodulus rounded.

\section{Sexual dimorphism}

Males may be distinguished externally from females by the slightly more slender elytra and the cavity and setae on ventrite 5 .

\section{Life history}

Phlyctinus callosus is a polyphagous species. Verified host plants belong to the families Amaryllidaceae (ornamental Tulbaghia spp.), Asteraceae (Osteospermum moniliferum L., ornamental Gazania sp.), Apiaceae (larvae have been artificially bred on Daucus carota L.), Aizoaceae (ornamental Lampranthus sp.), Crassulaceae (Cotyledon orbiculata L., Cotyledon spp.), Geraniaceae (ornamental Pelargonium sp.), Plantaginaceae (Plantago lanceolata L.) and Plumbaginaceae (ornamental Plumbago auriculata Lam.). This species is often found in gardens on ornamental plants. In natural habitats it was only found on $O$. moniliferum occurring in humid, sandy habitats such as river banks. Adults spend the day in the leaf litter on the ground in the vicinity of the host plant (Fig. 4A) and climb onto its aerial parts during the night to feed and mate. Adults may be found all year round if the habitat remains wet.

\section{Distribution}

Phlyctinus callosus is endemic to the Western Cape province of the republic of South Africa. Museum records suggest that this species is naturally distributed around Cape Town and on the Cape Flats. In other localities (Cederberg, Little Karoo, etc.) it has only been found in the vicinity of gardens and orchards, suggesting human-mediated transportation. The records of the species from the Eastern Cape province

Fig. 1 (opposite page). Habitus of species of Phlyctinus Schoenherr, 1826 males (left) and females (right). A. P. callosus (Schoenherr, 1826). B. P. grootbosensis Haran sp. nov. C. P. xerophilus Haran sp. nov., holotype $\hat{\sigma}$. D. P. planithorax Haran sp. nov., holotype $\hat{\sigma}$. E. P. littoralis Haran sp. nov., holotype $\hat{\sigma}$. F. $P$. aloevorus Haran sp. nov., holotype ${ }^{\lambda}$. Scale bars $=3 \mathrm{~mm}$. 
also probably correspond to human-mediated introductions. Phlyctinus callosus has been introduced into the following countries: Australia, New Zealand, Norfolk Island, Reunion Island and St Helena Island. The records from the Kermadec and Ascension Islands could not be verified and should be temporarily considered as referring to Phlyctinus species. This species has been detected, but seemingly not established, in the Northern Hemisphere: Britain (Brown 2004) and the USA (Anonymous 1950).

\section{Remarks}

In the collection of Schoenherr housed at NHRS, two males and two females from the type locality (Cape of Good Hope) and fitted with type and paratype labels were located under the name P. callosus. However, the description of this species lacks a designation of a particular specimen as the holotype (Schoenherr 1826). The male specimen from this series bearing a red type label (NHRS JLKB000065427) is designated as the lectotype for P. callosus (Schoenherr 1826). The second male of this series (NHRS JLKB000065428) bears a red paratype label, but belongs to a different, undescribed species, and will not be dealt within this paper. The two females of this series (NHRS JLKB000065429, NHRS JLKB000065430) were labelled as paralectotypes for $P$. callosus.

In the Wollaston collection housed at BMNH, the syntypic series of Sciobius subnodosus Wollaston, 1869 (1 $\hat{O}^{\lambda}, 2$ 우 ) from St Helena Island was located. The male specimen of this series is designated (above) as the lectotype for $S$. subnodosus. The two female specimens are labelled as paralectotypes of this species name. The examination of these specimens revealed no external or internal differences from the holotype of Phlyctinus callosus as reported in Decelle \& Voss (1972). The name P. callosus var. tottus Sparrman, 1785 (as listed by Lona 1937) does not refer to any species description of Sparmann and should be considered as an in litteris invalid name. The type material of Ocynoma rhysa Olliff, 1888 and Rhyncogonus germanus Broun, 1893 could not be located in the context of this study. These names are reported as synonyms of $P$. callosus by Marshall (1926) and Pullen et al. (2014).

Uncorrected genetic p-distances of COI reached 1.6\% among all the specimens of this species as analyzed (Fig. 5).

Phlyctinus grootbosensis Haran sp. nov. urn:1sid:zoobank.org:act:E9F2C348-E57C-4B83-A464-7E6F1896BF12

Figs 1B, 2B, 3B, 4C

\section{Etymology}

This species is named in reference to its type locality, the Grootbos Private Nature Reserve. As knowledge stands, this species is endemic to this place.

\section{Material examined}

\section{Holotype}

REPUBLIC OF SOUTH AFRICA - $\widehat{\alpha}$; Western Cape province, Gansbaai, Grootbos Private Nature Reserve: 3432.356' S, 19²4.683' E; 6 Jun. 2018; J. Haran leg.; at base of Senecio burchellii DC.; CBGP code JHAR01082; SAMC.

\section{Paratypes}

REPUBLIC OF SOUTH AFRICA • 1 ô, 1 o ; same collection data as for holotype; $34^{\circ} 31.609^{\prime} \mathrm{S}$, 19²9.453' E; 10 Aug. 2018; J. Haran leg.; sweeping by night, on Osteospermum moniliferum; CBGP

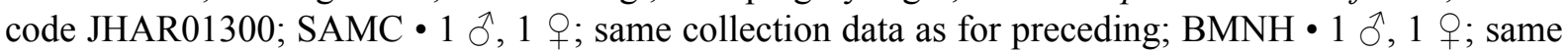
collection data as for preceding; CBGP $\bullet 1 \hat{\partial}, 1$; same collection data as for preceding; SANC $\bullet 1 \hat{\jmath}$, 1 \&; same collection data as for preceding; SUIC. $1 \curvearrowright, 1$; same collection data as for preceding; TMSA. 

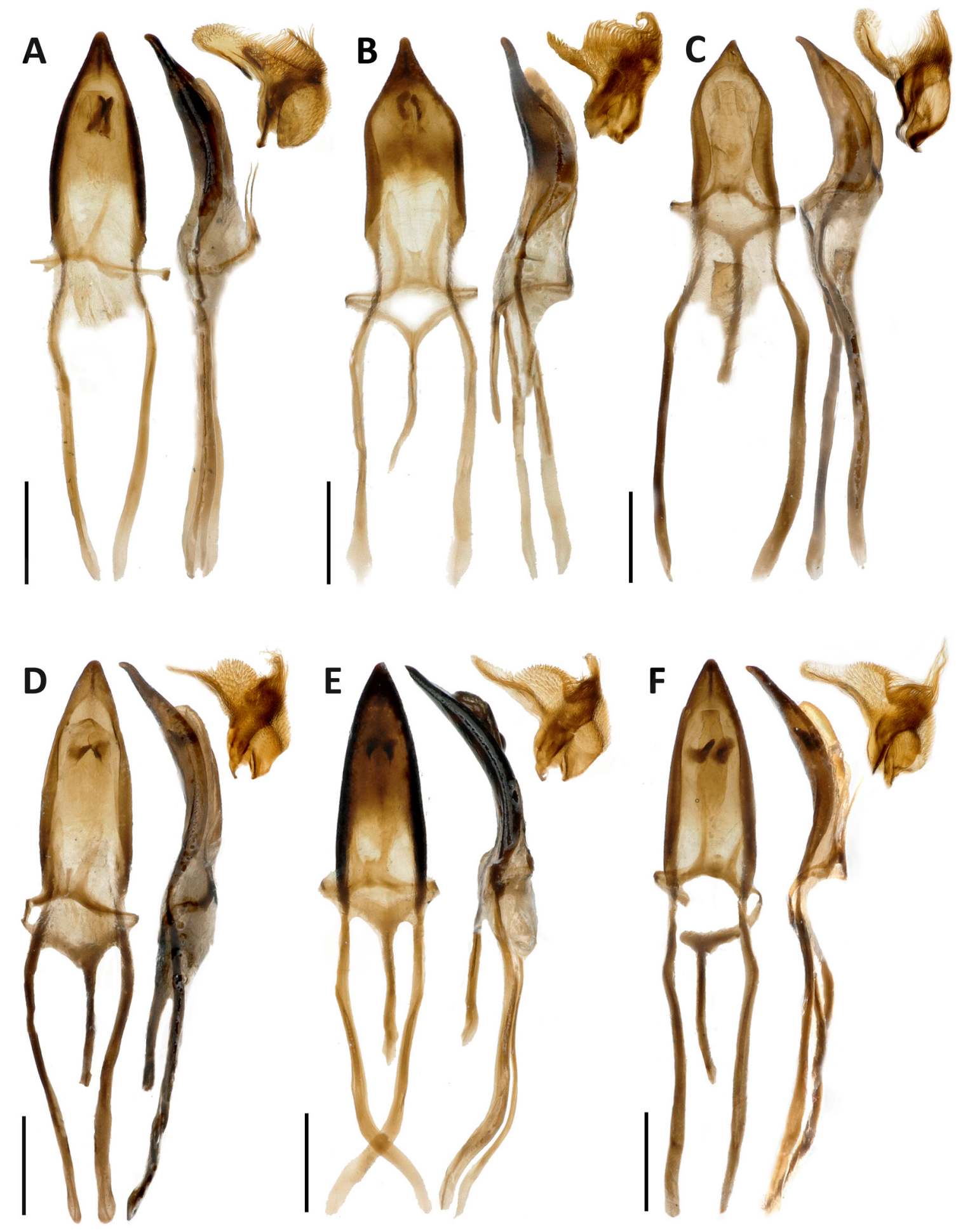

Fig. 2. Penis of Phlyctinus Schoenherr, 1826, in dorsal (left) and lateral (right) view, and copulatory sclerite (top right). A. P. callosus (Schoenherr, 1826). B. P. grootbosensis Haran sp. nov. C. P. xerophilus

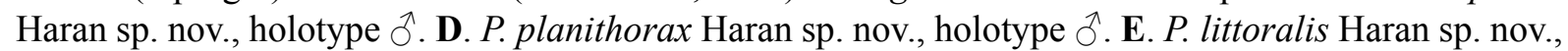
holotype $\hat{\delta}$. F. P. aloevorus Haran sp. nov., holotype $\hat{\delta}$. Scale bars $=500 \mu \mathrm{m}$. Copulatory sclerite not to scale. 


\section{Description}

BODY LENGTH. 5.2-6.5 mm.

Colour. Body integument black, legs black to dark red; vestiture of elytra consisting of a mixture of scales, either isodiametric to twice as long as wide, pearly white or smaller, $3 \times$ as long as wide, brown, not concealing the integument; pearly white scales forming series of pale dots on interstriae or illdefined transverse bands, and a band on basal half of sides of prothorax.

HEAD. Rostrum longer than wide (w/1 ratio: 0.67 ) in both sexes, at base $1.05 \times$ as wide as at apex, sides slightly concave near middle of length; epifrons in middle as wide as width of eye, at base narrower than distance between eyes, sides subparallel, slightly expanding apicad, upper face with a longitudinal carina extending from basal transversal groove to nasal plate, visible through scales; nasal plate V-shaped, reaching level of antennal insertion basally, bare of scales, with only minute setae inserted in scattered punctures and 3 pairs of long setae apically near insertion of mandibles ( 2 short and 1 very long); antennal scrobes slightly curved in lateral view, directed to middle of eye, separated from it by a strip of scales $1 / 4$ as wide as width of eyes; mandibles trisetose, bare of scales. Forehead with a short longitudinal furrow between eyes, scales and setae arranged centripetally towards a point below base of eyes; eyes moderately protruding, margin slightly more convex basally than apically. Antennae slender, scape $0.70 \times$ as long as funicle, slightly bisinuate, subclavate at apex, exceeding anterior margin of prothorax in repose; funicle with segments 1-2 elongate, 1 shorter $(0.82 \times)$ than 2 , segments 3-6 longer than wide, conical, shortening apicad, segment 7 longer and slightly wider than 6; club spindle-shaped, segment 1 longer than 2 , margins slightly sinuous.

Prothorax. Slightly wider than long (w/l ratio: 1.16), widest slightly before middle of length, apical margin $0.58 \times$ as wide as at base, sides sub-straight in apical and basal $1 / 2$, almost angular at widest point; integument forming a dense cover of elongate granules forming concentric ellipses around a point located on basal $1 / 3$ of median line and a pair of slight depressions on each side of this point; median carina absent, integument not forming a smooth and shiny ridge.

ELYTRA. Sides convex, widest before middle of length (w/1 ratio: $0.72-0.77$ ), integument smooth or weakly reticulate, shiny or matt, interstriae raised, $2-4 \times$ as wide as width of striae in basal half; declivital callosities present on apical $1 / 4$ of interstriae 3,5 and 7 and smaller ones on 2, 4, 6 and 8 ; each interstria with a series of semi-erect, elongate whitish scales, condensed on callosities.

AвDOMEN. Underside with pearly green or pearly white scales, not concealing integument, not condensed on metanepisterna; ventrite 1 slightly shorter than $2+3+4$, slightly convex in middle ( + ), or concave with very long, erect golden setae much longer than claws $\left(\delta^{\top}\right)$, ventrite 5 longer than $3+4$, with erect setae in middle and near apex and a reticulate ridge near apex ( $(+)$ or with a large cavity in apical $4 / 5$, with long erect setae, similar to those on ventrite 1, condensed on 2 brushes on each side of margin of cavity; setae in bottom of cavity erect, golden, shorter than those on margin ( $\delta^{\Uparrow}$ ) (Fig. 3B); in males, middle of ventrites 1-4 with an elongate cuticular ridge at base of setae.

LeGs. Femora clavate, unarmed, with a ring of more condensed pale scales near middle; tibiae straight, unarmed, slightly bisinuate on ventral side; in males apex of metatibia with a brush of golden setae ventrally; claws simple, free, equal in length.

Genitalia. Body of penis short, $0.6 \times$ as long as apodemes (w/1 ratio: 0.48 ), sides subparallel in basal half, widest near base, concave in apical $1 / 3$, tapering towards apex; apex pointed; in lateral view curvature weak, mainly in basal half, bisinuate near apex (Fig. 2B); copulatory sclerite with left arm shorter than 
body, bearing setae at base, comb of right arm with setae converging and forming a spiral; right area of body as wide as left area.

\section{Sexual dimorphism}

Males might be distinguished externally from females by the slightly more slender elytra and the two brushes of erect golden setae on ventrites 1 and 5 .

\section{Life history}

This species was found to be abundant on and at the base of Osteospermum moniliferum, Senecio halimifolius L. and S. burchellii, which are probably its host plants (Fig. 4D).

\section{Distribution}

Phlyctinus grootbosensis sp. nov. is only known from the type locality, the Grootbos Private Nature Reserve near Gansbaai.

\section{Remarks}

Phlyctinus grootbosensis sp. nov. can easily be distinguished from other species by the long golden setae on ventrites 1 and 5 of the males. It is the darkest species of the genus and has the most strongly rounded eyes in dorsal view (more or less angled in the other species). Its body shape and colour resemble the dry fruits of Osteospermum moniliferum remarkably well (Fig. 4C).

Phlyctinus xerophilus Haran sp. nov. urn:lsid:zoobank.org:act:4B53AE34-6D14-4365-BD47-762A6596ED1B

Figs $1 \mathrm{C}, 2 \mathrm{C}, 3 \mathrm{C}, 4 \mathrm{~B}$

\section{Etymology}

This species is named in reference to its known distribution range, which comprises dryer and warmer inland habitats than those of the other species of the genus.

\section{Material examined}

\section{Holotype}

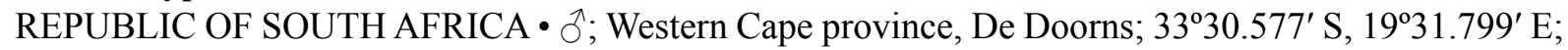
23 Jul. 2019; S. Hansen leg.; at base of Plantago lanceolata; CBGP code JHAR02442; SAMC.

\section{Paratypes}

REPUBLIC OF SOUTH AFRICA - Western Cape province -1 ; same collection data as for

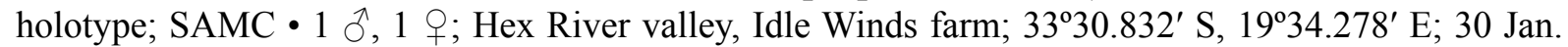

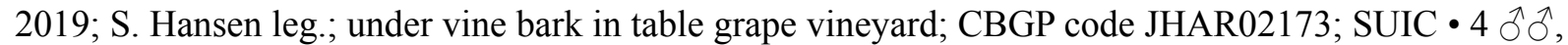
3 우; same locality as for preceding; 10 Dec. 2019; S. Hansen and J. Haran leg.; at base of table grape vineyard; CBGP code JHAR03097; CBGP • 3 ô ô, 1 क ; De Doorns; $33.28^{\circ} \mathrm{S}, 19.43^{\circ} \mathrm{E}$; 18 Nov. 1982;

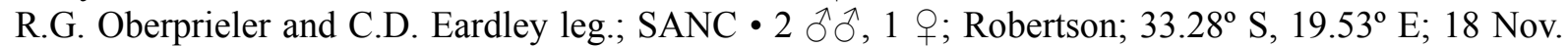
1983; A. Schwartz; SANC.

\section{Description}

Body LENGTH. 7.0-8.0 mm.

Colour. Body integument dark red, head and prothorax darker, usually black; vestiture of elytra consisting of a dense cover of small, elliptic scales, slightly longer than wide, not completely concealing 

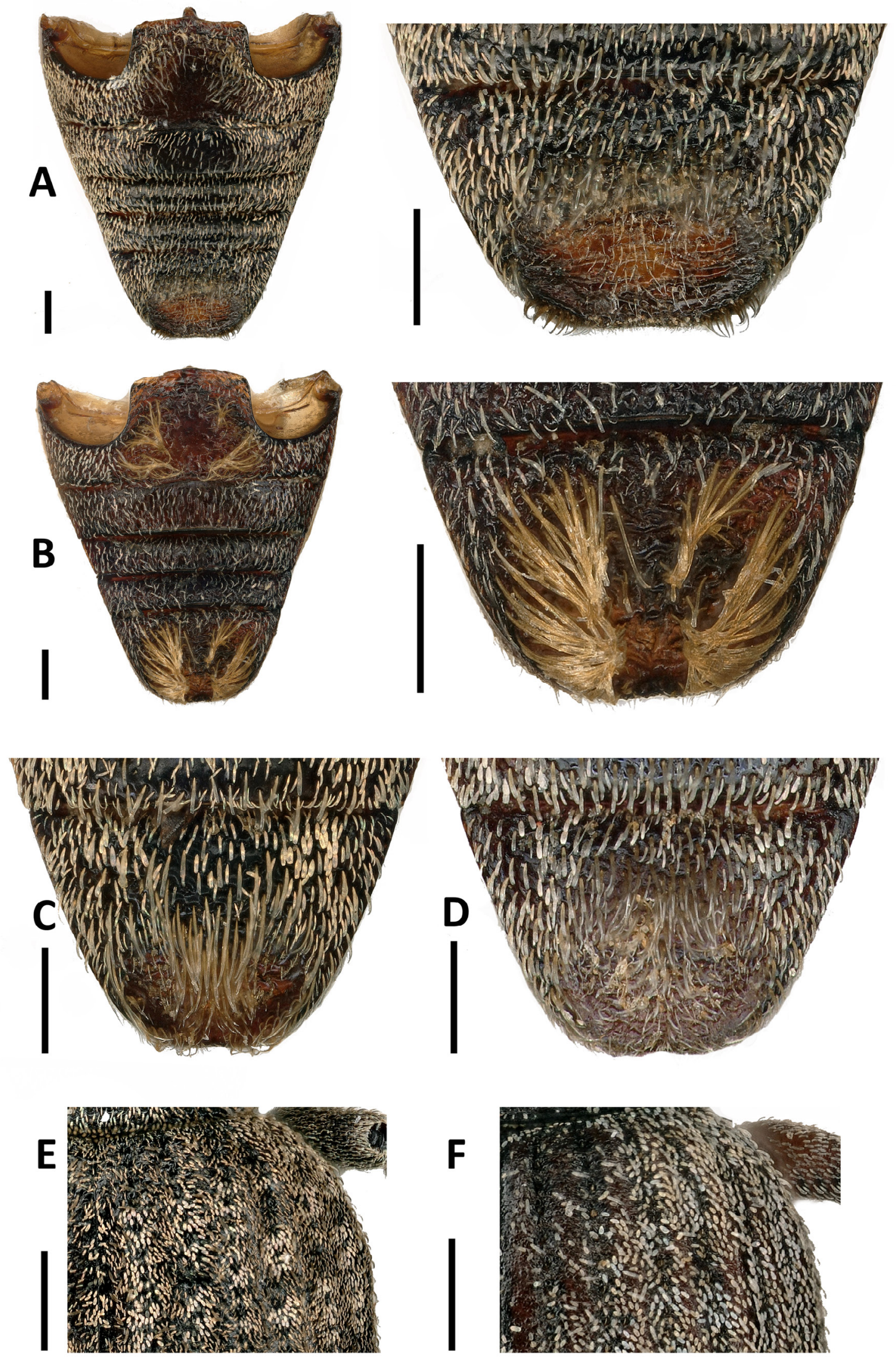
integument; scales pale brown with spots of pearly green scales generally forming a transverse band in apical $2 / 3$ of elytra, a short strip at base on $3^{\text {rd }}$ interstria, longitudinal bands on basal half of sides of prothorax and a few dots on apical margin of prothorax.

HEAD. Rostrum longer than wide (w/1 ratio: 0.80) in both sexes, base as wide as apex, sides slightly concave near middle of length; epifrons as wide at base as width of eye, at base narrower than distance between eyes, sides widening from base to apex, upper face with a longitudinal carina extending from basal transverse groove to nasal plate, visible through scales; nasal plate V-shaped, reaching level of antennal insertion basally, bare of scales, with short setae inserted in scattered punctures and 3 pairs of long setae apically near insertion of mandibles ( 2 short and 1 very long); antennal scrobes slightly curved in lateral view, directed to middle of eye, separated from it by a strip of scales as wide as diameter of eyes; mandibles trisetose, bare of scales. Forehead with a short longitudinal furrow between eyes, scales and setae arranged centripetally towards a point below base of eyes. Eyes protruding, surface almost conical in dorsal view. Antennae slender, scape $1.25 \times$ as long as funicle, slightly bisinuate, subclavate at apex, exceeding anterior margin of prothorax in repose; funicle with segments 1-2 elongate, 1 shorter $(0.70 \times)$ than 2 , segments 3-7 longer than wide, conical, 3-5 shortening apicad, 5-6 widening apicad; club spindle-shaped, segment 1 longer than 2 , margins slightly sinuous.

Prothorax. Slightly wider than long (w/l ratio: 1.20), widest slightly before middle of length, apical margin $0.75 \times$ as wide as base, sides rounded, apical half slightly concave; integument forming a dense cover of elongate granules orientated parallel to median carina and two slight depressions on each side of median carina; median carina raised, smooth and shiny, not reaching apical and basal margins of prothorax.

ELYTRA. Sides slightly convex, widest before middle of length (w/l ratio: 0.73-0.77), integument smooth, shiny, finely punctate, interstriae raised, $2-4 \times$ as wide as width of striae in basal half; large declivital callosities present on apical $1 / 4$ of interstriae 3,5 and 7 and smaller ones on 2, 4, 6 and 8 ; each interstria with a series of semi-erect, elongate whitish scales, condensed on callosities.

ABDomen. Underside with pearly green or pearly brown scales, not concealing integument, more condensed on metanepisterna; ventrite 1 shorter than $2+3+4$, slightly convex in middle ( + ) or concave with erect setae slightly shorter than claws $(\precsim)$, ventrite 5 longer than $3+4$, with erect setae in middle and near apex and a smooth longitudinal carina ( $(9)$ or with large cavity extending on apical $2 / 3$, with long erect setae condensed on margins and along a longitudinal line at bottom of cavity ( $\overbrace{}^{\lambda})$ (Fig. 3C).

LEGS. Femora clavate, unarmed, with a ring of more condensed pale scales near middle; tibiae straight, unarmed, slightly bisinuate on ventral side; claws simple, free, equal in length.

Genitalia. Body of penis short, $0.5 \times$ as long as apodemes, sides bisinuate, widest above middle of length, converging from there towards apex, apex pointed (w/1 ratio: 0.50$)$, in lateral view curvature weak and regular (Fig. 2C); endophallus with a sclerotised plate forming a square angle below base of body of penis; copulatory sclerite with left arm as long as body, strongly curved inwards, not bearing setae; comb of right arm with setae converging; right area of body wider than left area.

Fig. 3 (opposite page). A-B. Ventrites of males of Phlyctinus Schoenherr, 1826 (left: ventrites 1-5, right: ventrite 5). A. P. callosus (Schoenherr, 1826). B. P. grootbosensis Haran sp. nov. C-D. Ventrite 5.

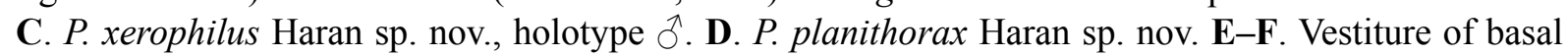
right side of elytra. E. P. callosus (Schoenherr, 1826) (left). F. P. littoralis Haran sp. nov. Scale bars = $0.5 \mathrm{~mm}$. 


\section{Sexual dimorphism}

Males may be distinguished externally from females by the cavity and setae on ventrite 5 .

\section{Life history}

Adults of P. xerophilus sp. nov. have been found at the base of vines and Plantago lanceolata plants in table grape vineyards (Fig. 4B). The host plants of the larvae are unknown. Adults were collected in January, July, September and December.

\section{Distribution}

As currently known, this species seems to occur naturally in the region of Robertson and the Hex River valley.

\section{Remarks}

Phlyctinus xerophilus sp. nov. is similar to $P$. callosus but differs from it by the erect setae along the median line of the cavity of ventrite 5 of the males (Fig. 3C). It is also slightly larger, more elongate and has larger elytral tubercles on the declivity than $P$. callosus. Females of the two species are difficult to distinguish morphologically. As knowledge stands, there seems to be only a small overlap between their distribution ranges and therefore the geographical origin of specimens can assist in their identification. The two species can also be distinguished using their $C O I$ sequences, which show divergences ranging from 9.2 to $9.8 \%$.

The sequencing of other specimens morphologically similar to P. xerophilus sp. nov. (Table 1) showed that this species contains at least four mitochondrial lineages (Fig. 5) found in populations from distinct localities. Uncorrected p-distances between all these lineages ranged from 5.5 and $8.5 \%$. Preliminary observations made on series of specimens from these localities showed subtle morphological differences that suggest that this species could be a complex of closely related or cryptic species. A formal treatment of this complex has not been undertaken here due to limited fresh material available. It will be the focus of a future study. All specimens found to date run to P. xerophilus sp. nov. in the key provided. As knowledge stands, only the specimens described formally here as $P$. xerophilus sp. nov. are agricultural pests. Other specimens were found in natural or semi-natural habitats.

Phlyctinus planithorax Haran sp. nov. urn:1sid:zoobank.org:act:6D17741D-DBF6-4AF3-BD2B-DBBF5F0ADD8A

Figs $1 \mathrm{D}, 2 \mathrm{D}, 3 \mathrm{D}, 4 \mathrm{E}$

\section{Etymology}

The species name refers to the absence of a median carina on the prothorax of this species.

\section{Material examined}

\section{Holotype}

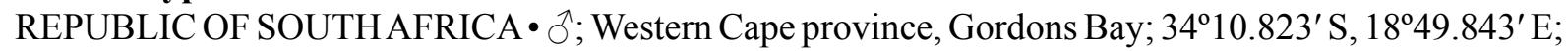
14 Apr. 2019; at base of Hymenolepis crithmifolia (L.) Greuter (Asteraceae); CBGP code JHAR02264; SAMC.

\section{Paratypes}

REPUBLIC OF SOUTH AFRICA - Western Cape province $\cdot 2 \hat{\jmath} \widehat{\partial}, 2+q$; same collection data as

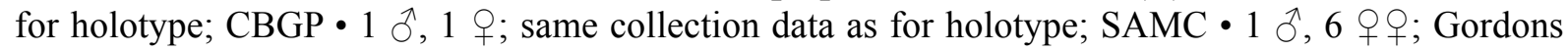
Bay; $34^{\circ} 10.093^{\prime}$ S, $18^{\circ} 51.047^{\prime}$ E; 8 Nov. 2019; at base of Hymenolepis crithmifolia; CBGP code

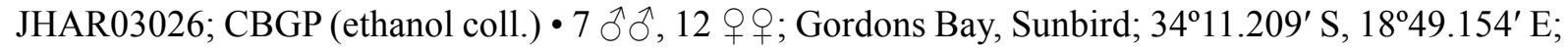


8 Nov. 2019; at base of Carpobrotus edulis (L.) N.E.Br (Aizoaceae); CBGP code JHAR03027; CBGP (ethanol coll.).

\section{Description}

Body LENGTH. 6.0-6.8 mm.

Colour. Body integument black; vestiture of elytra consisting of elliptical scales, twice as long as wide, not concealing integument; scales pale or dark brown with scattered contrasting pearly green spots and an ill-defined transverse pale band on apical $2 / 3$ of interstriae $1-3$, mainly visible in females.

HEAD. Rostrum longer than wide (w/1 ratio: 0.77 ) in both sexes, as wide as base at apex, sides slightly concave near middle of length in dorsal view; epifrons as wide as width of eye, at base narrower than distance between eyes, sides subparallel, upper face with a longitudinal carina extending from basal transverse groove to nasal plate, visible through scales; nasal plate V-shaped, reaching level of antennal insertions basally, bare of scales, with only minute setae inserted in scattered punctures and 3 pairs of long setae apically near insertion of mandibles ( 2 short and 1 very long); antennal scrobes slightly curved in lateral view, directed to middle of eye, separated from it by a strip of scales slightly narrower than diameter of eyes; mandibles trisetose, bare of scales. Forehead with a short longitudinal furrow between eyes; recumbent and suberect scales arranged centripetally towards a point below base of eyes, in dorsal view; eyes protruding, surface almost conical in dorsal view. Antennae slender, scape $0.75 \times$ as long as funicle, slightly bisinuate, subclavate at apex, exceeding anterior margin of prothorax in repose; funicle with segments $1-2$ elongate, 1 very slightly shorter $(0.95 \times)$ than 2 , segments $3-6$ longer than wide, conical, shortening apicad, segment 7 longer and slightly wider than 6; club spindle-shaped, segment 1 longer than 2, margins slightly sinuous.

Prothorax. Wider than long (w/1 ratio: 1.18 ), widest near middle of length, apical margin $0.6 \times$ as wide as basal margin, sides rounded, apical half slightly concave; integument densely punctate, spaces between punctures forming ill-defined concentric smooth ridges, upper face regularly convex, lacking carina or cuticular depression.

ELYTRA. Sides convex, widest before middle of length (w/1 ratio: 0.75-0.80), integument micro-punctate and weakly reticulate, shiny, interstriae raised, $2-3 \times$ as wide as width of striae in basal half; small declivital callosities present on apical $1 / 4$ of interstriae 3,5 and 7 ; each interstria with $1-2$ series of semierect elongate brownish scales, condensed on callosities.

АвDомen. Underside with pearly green scales, scattered, not overlapping; ventrite 1 shorter than $2+3+4$, slightly convex in middle ( $(+)$ or concave with erect setae as long as claws $(\precsim)$, ventrite 5 as long as $3+4$, with sub-erect setae in middle and near apex $(+)$ or with a large cavity extending on apical $4 / 5$, with long erect setae condensed on margin of cavity, forming two brushes at apical and basal margins, and a longitudinal line of erect setae in cavity, long in basal half and very short in apical half (ठ̋) (Fig. 3D).

LEGS. Femora clavate, unarmed; tibiae straight, unarmed, slightly bisinuate on ventral side; claws simple, free, equal in length.

Genitalia. Body of penis elongate, $0.65 \times$ as long as apodemes, sides convex, widest in basal $1 / 4$ (w/l ratio: 0.44), in lateral view curvature weak (Fig. 2D); copulatory sclerite with left arm longer than body, not bearing setae at base; comb of right arm with setae converging, curved inward at apex; right area of body slightly wider than left area. 

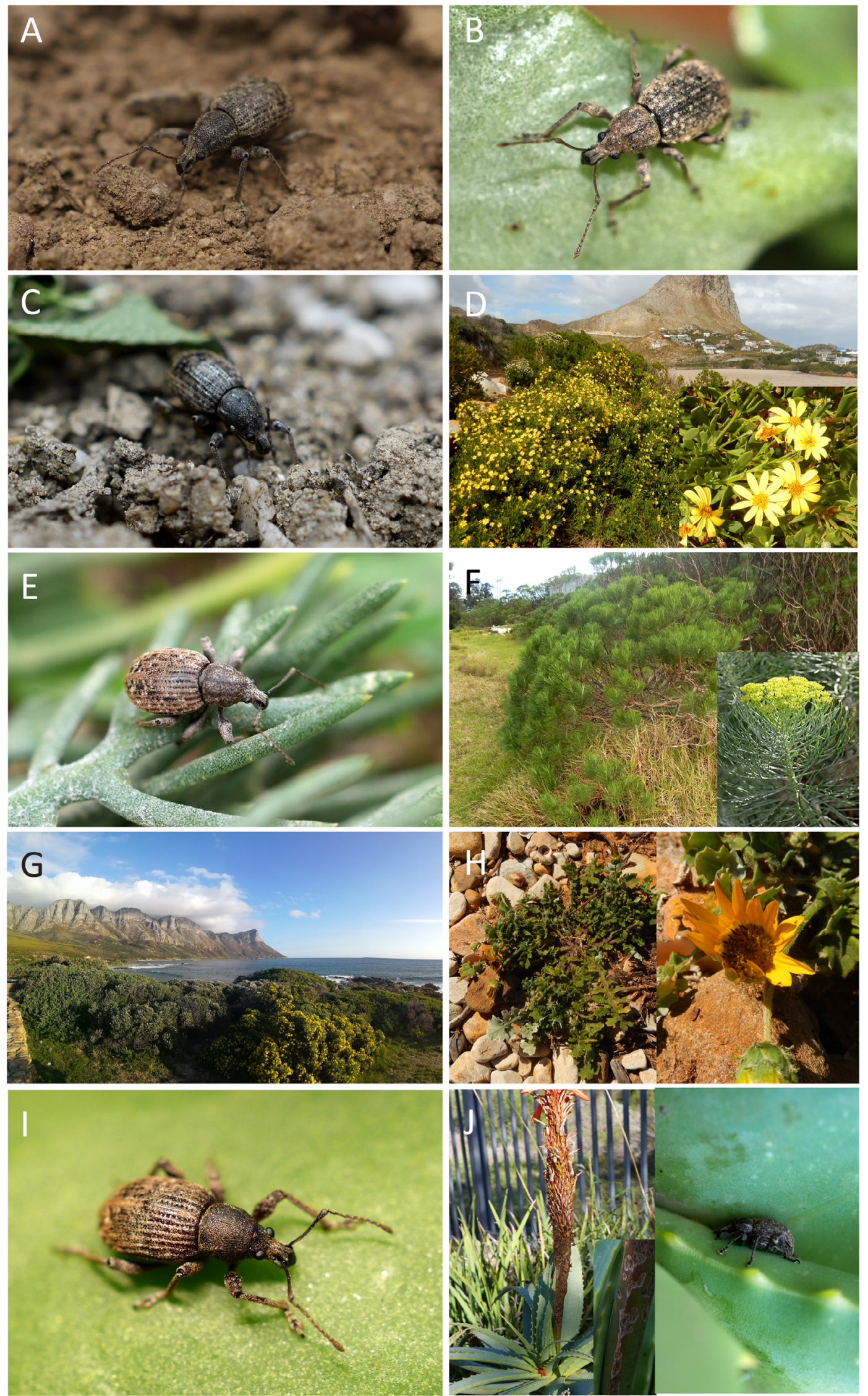


\section{Sexual dimorphism}

Males may be distinguished externally from females by the presence of a cavity and setae on ventrite 5 . They usually lack a distinct transverse pale band on the elytra (visible on interstriae 1-3 in females).

\section{Life history}

All known specimens of P. planithorax sp. nov. have been collected at the base of Hymenolepis crithmifolia (Asteraceae) and Carpobrotus edulis (Aizoaceae) plants, which are probably its host plants (Fig. 4E-F). This species was not found on other plants present at the collection sites. Adults were collected in April and November.

\section{Distribution}

This species is only known from several sites of the western slope of the Kogelberg Mountain.

\section{Remarks}

Phlyctinus planithorax sp. nov. belongs to the P. littoralis sp. nov. species group and is similar to the other species included in it. Based on the series examined, it can be distinguished from them by the absence of a carina on its prothorax and by the erect scales on ventrites $1-4$, which are more than twice as long as the recumbent scales (less than twice as long in P. littoralis sp. nov. and P. aloevorus sp. nov.). Phlyctinus planithorax sp. nov. is genetically closest to $P$. aloevorus sp. nov., the two species showing an interspecific uncorrected p-distance of $5.2 \%$. The arrangement of erect setae on ventrite 5 of this species is similar to that of $P$. xerophilus sp. nov., but the erect setae on the median line are shorter and do not reach the apex of the cavity. Despite an intense search for Phlyctinus species in coastal habitats in the Western Cape province, this species was only found at the vicinity of its type locality.

\section{Phlyctinus littoralis Haran sp. nov. urn:1sid:zoobank.org:act:49467405-4829-4E45-A2A5-70130EDA95E8}

Figs 1E, 2E, 3F

\section{Etymology}

Phlyctinus littoralis sp. nov. is named in reference to the coastal habitat in which it was found and to which it seems to be restricted.

\section{Material examined}

\section{Holotype}

REPUBLIC OF SOUTH AFRICA • ${ }^{\top}$; Western Cape province, Kogel Bay; $34^{\circ} 14.617^{\prime}$ S, $18^{\circ} 51.174^{\prime}$ E; 12 May 2018; at base of Arctotis angustifolia L. (Asteraceae); CBGP code JHAR00973; SAMC.

\section{Paratypes}

REPUBLIC OF SOUTH AFRICA $\bullet 2 \hat{\jmath} \widehat{\partial}, 2$ 우; same collection data as for holotype; 16 Sep. 2018 ; $\mathrm{CBGP} \bullet 1 \hat{\partial}, 1$; ; same collection data as for preceding; SANC.

Fig. 4 (opposite page). Habitus in natura, host plants and biotopes of Phlyctinus Schoenherr, 1826 species. A. P. callosus (Schoenherr, 1826). B. P. xerophilus Haran sp. nov. C-D. P. grootbosensis Haran sp. nov. and its host plant, Osteospermum moniliferum L. E-F. P. planithorax Haran sp. nov. and its host plant, Hymenolepis crithmifolia (L.) Greuter. G-H. Biotope and host plant (Arctotis angustifolia L.) of P. littoralis Haran sp. nov. I-J. P. aloevorus Haran sp. nov. on its host plant, Aloe arborescens Mill., with details of feeding damage on floral peduncle. 


\section{Description}

BODY LENGTH. 5.2-6.4 mm.

Colour. Body integument dark red, head and prothorax darker, usually black; vestiture of elytra with elliptic elongate scales, twice as long as wide, not concealing integument, greyish, forming a homogeneous grey appearance, usually with an ill-defined paler band on apical $2 / 3$ of interstriae 1-3.

HEAD. Rostrum longer than wide (w/1 ratio: 0.63 ) in both sexes, at base as wide as at apex, sides slightly concave near middle of length; epifrons slightly narrower in middle of length than width of eye in dorsal view, at base narrower than distance between eyes, sides subparallel, slightly widening apicad, upper face with a longitudinal carina extending from basal transverse groove to nasal plate, visible through scales; nasal plate $\mathrm{V}$-shaped, reaching level of antennal insertion basally, bare of scales, with only minute setae inserted in scattered punctures and 3 pairs of long setae apically near insertion of mandibles ( 2 short and 1 very long); antennal scrobes slightly curved in lateral view, directed to middle of eye, separated from it by a strip of scales half as narrow as diameter of eyes; mandibles trisetose, bare of scales. Forehead with a short longitudinal furrow between eyes, scales and setae arranged centripetally towards a point below base of eyes; eyes protruding, margin rounded, surface slightly conical in dorsal view. Antennae slender, scape $0.8 \times$ as long as funicle, slightly bisinuate, subclavate at apex, exceeding anterior margin of prothorax in repose; funicle with segments $1-2$ elongate, 1 slightly shorter $(0.85 \times)$ than 2 , segments 3-6 longer than wide, conical, shortening apicad, segment 7 longer and slightly wider than 6; club spindle-shaped, segment 1 longer than 2, margins slightly sinuous.

PRothorax. Slightly wider than long (w/l ratio: 1.20 ), widest near middle of length, apical margin $0.6 \times$ as wide as basal margin, sides rounded, apical half slightly concave; integument densely punctate, spaces between punctures forming ill-defined, concentric smooth ridges and a small, smooth and shiny median carina visible in approximately $50 \%$ of individuals; upper face regularly convex, lacking depressions.

ELYTRA. Sides convex, widest near middle of length (w/1 ratio: 0.76-0.83), integument finely punctate and reticulate, shiny, interstria raised, $3-4 \times$ as wide as width of striae in basal half; large declivital callosities absent or very reduced in apical $1 / 4$ of interstriae 3,5 and 7 ; each interstria with a series of semi-erect elongate whitish scales, slightly more condensed in spots on declivity.

AвDOMEN. Underside with scattered scales similar to those on elytra, not concealing integument; ventrite 1 as long as $2+3+4$, slightly convex in middle ( $(+)$, or concave with erect setae as long as claws $\left(\delta^{\pi}\right)$, ventrite 5 longer than $3+4$, with recumbent elongate setae in middle and near apex and a weak longitudinal carina near apex $(+$ ) or with a large cavity extending over apical $2 / 3$, with long erect setae mainly condensed on middle of basal margin of cavity and a brush on either side of apical margin; bottom of cavity with a few short recumbent or semi-erect setae $(\delta)$.

LEGS. Femora clavate, unarmed, with a double vestiture of recumbent and semi-erect greyish scales; tibiae straight, unarmed, slightly bisinuate on ventral side; claws simple, free, equal in length.

GeNITALIA. Body of penis elongate, $0.75 \times$ as long as apodemes, sides almost straight, converging regularly towards apex, more abruptly near apex, widest at base (w/1 ratio: 0.40), in lateral view curvature weak, slightly stronger near middle of length (Fig. 2E); copulatory sclerite with left arm longer than body, not bearing setae at base; comb of right arm with setae converging; right area of body slightly wider than left area. 


\section{Sexual dimorphism}

Males may be distinguished externally from females by the slightly more slender elytra (w/1 ratio: 0.76 , 0.83 in + ) and the cavity and setae on ventrite 5 .

\section{Life history}

The type series of $P$. littoralis sp. nov. was collected from the base of Arctotis angustifolia (Asteraceae) plants growing on the gravel parts of Kogel Bay beach (Fig. 4G-H). Adults were collected between May and September but gravid females only in May.

\section{Distribution}

This species is only known from its type locality.

\section{Remarks}

Phlyctinus littoralis sp. nov., P. planithorax sp. nov. and P. aloevorus sp. nov. form a species group characterized by the presence of only very small or no tubercles on the elytral declivity and short setae on ventrite 1 of the males. Preliminary phylogenetic analysis of $C O I$ sequences indicated that they form a distinct genetic cluster (Fig. 5). They have so far only been found in coastal habitats. Phlyctinus littoralis sp. nov. is most closely related to $P$. planithorax sp. nov., from which it can easily be distinguished by its homogeneous grey vestiture. The two species show an interspecific genetic p-distance on COI of $4.6 \%$.

Phlyctinus aloevorus Haran sp. nov.

urn:1sid:zoobank.org:act:28603A47-8AF4-4676-A2E2-BC82092AD72A

Figs 1F, 2F, 4I-J

\section{Etymology}

This species name is formed from the genus name of its main host plant, Aloe arborescens Mill., on which it causes distinct feeding damage.

\section{Material examined}

\section{Holotype}

REPUBLIC OF SOUTH AFRICA • ${ }^{\uparrow}$; Western Cape province, Betty's Bay; $34^{\circ} 21.145^{\prime} \mathrm{S}, 18^{\circ} 54.765^{\prime} \mathrm{E}$; 23 Mar. 2019; J. Haran leg.; on Aloe arborescens; CBGP code JHAR02252; SAMC.

\section{Paratypes}

REPUBLIC OF SOUTH AFRICA - Western Cape province $\bullet 3 \hat{\partial} \hat{\partial}, 3 q+q$; same collection data as for holotype; CBGP• 1 ô, 1 क ; same collection data as for holotype; SAMC • 3 specs; Betty's Bay, Botanical Garden; 34²1'04.20" S, 1855'37.73" E; 24 Nov. 2019; J. Haran leg.; on Aloe arborescens; CBGP code JHAR03063; CBGP (ethanol coll.) • 1 ○े, 6 specs; Kleinmond; 34²0'33.70" S, 1900'53.47" E; 24 Nov. 2019; J. Haran leg.; on Aloe arborescens and Carpobrotus edulis; CBGP code JHAR03064; CBGP (ethanol coll.).

\section{Description}

BODY LENGTH. 5.5-6.5 mm.

Colour. Body integument dark red, head and prothorax darker, usually black; vestiture of elytra with elliptic elongate scales, twice as long as wide, not concealing integument; scales brown with scattered ill-defined paler spots, in females with a pale transverse band on apical 1/4 of interstriae 1-3. 
HEAD. Rostrum longer than wide (w/1 ratio: 0.72 ) in both sexes, at base as wide as at apex, sides slightly concave near middle of length; epifrons slightly narrower in middle of length than width of eye in dorsal view, at base slightly narrower than distance between eyes, sides subparallel, slightly widening apicad, upper face with a longitudinal carina extending from basal transverse groove to nasal plate, visible through scales; nasal plate V-shaped, reaching level of antennal insertion basally, bare of scales, with only minute setae inserted in scattered punctures and 3 pairs of long setae apically near insertion of mandibles ( 2 short and 1 very long); antennal scrobes slightly curved in lateral view, directed to middle of eye, separated from it by a strip of scales half to $1 / 3$ narrower than diameter of eye; mandibles trisetose, bare of scales. Forehead with a short longitudinal furrow between eyes, scales and setae arranged centripetally towards a point below base of eyes; eyes protruding, margin rounded, surface moderately conical in dorsal view. Antennae slender, scape $0.7 \times$ as long as funicle, bisinuate, subclavate at apex, exceeding anterior margin of prothorax in repose; funicle with segments $1-2$ elongate, 1 slightly shorter $(0.87 \times)$ than 2, segments 3-6 longer than wide, conical, shortening apicad, segment 7 longer and slightly wider than 6; club spindle-shaped, segment 1 longer than 2, margins slightly sinuous.

Prothorax. Slightly wider than long (w/l ratio: 1.18), widest before middle of length, apical margin $0.7 \times$ as wide as basal margin, sides rounded, apical half slightly concave; integument densely punctate, with shiny elongate concentric ridges and a median carina; upper face regularly convex, lacking cuticular depression.

ElytRA. Sides convex, widest near middle of length (ratio w/l: 0.79-0.83), integument finely punctate and reticulate, shiny, interstriae raised, $3-4 \times$ as wide as width of striae in basal half; large declivital callosities absent or very reduced in apical $1 / 4$ of interstriae 3,5 and 7 ; each interstria with a series of semi-erect, elongate pale brown scales, slightly more condensed on callosities.

ABDOMEN. Underside with scattered scales similar to those on elytra, not concealing integument; ventrite 1 shorter than $2+3+4$, slightly convex in middle $(+$ ) or concave with sub-erect setae shorter than claws $\left({ }^{\Uparrow}\right)$, ventrite 5 longer than $3+4$, with recumbent elongate setae in middle and near apex and a weak longitudinal carina near apex (ㅇ) or with a large cavity extending over apical $3 / 4$, with long erect setae mainly condensed at middle of basal margin of cavity and a brush on each side of apical margin; bottom of cavity with a few short recumbent or semi-erect setae $\left(\delta^{\Uparrow}\right)$.

LEGs. Femora clavate, unarmed, with double vestiture of recumbent and semi-erect greyish scales; tibiae straight, unarmed, slightly bisinuate on ventral side; claws simple, free, equal in length.

Genitalia. Body of penis elongate, $0.75 \times$ as long as apodemes, sides convex, widest slightly before middle of length (w/l ratio: 0.36), in lateral view curvature weak, stronger near base (Fig. 2F); copulatory sclerite with left arm longer than body, bearing setae at base; comb of right arm with setae converging, curved, straight at apex; right area of body slightly wider than left area.

\section{Sexual dimorphism}

Males may be distinguished externally from females by the homogenous elytral vestiture (with a transverse pale band in apical $1 / 3$ in females), and the cavity and erect setae on ventrite 5 .

\section{Life history}

Phlyctinus aloevorus sp. nov. (Fig. 4I) forms large populations on Aloe arborescens (Asphodelaceae) and, to a lesser extent, on Carpobrotus edulis (Aizoaceae). Contrary to other species of the genus, which spend the day sheltering in the leaf litter, $P$. aloevorus sp. nov. was found hidden between the young leaves of Aloe L. during the day (Fig. 4J), feeding mainly on flower peduncles (Fig. 4J). Adults were collected in March and November. 


\section{Distribution}

This species was only found at various limited locations on the Cape coast between Betty's Bay and Hermanus.

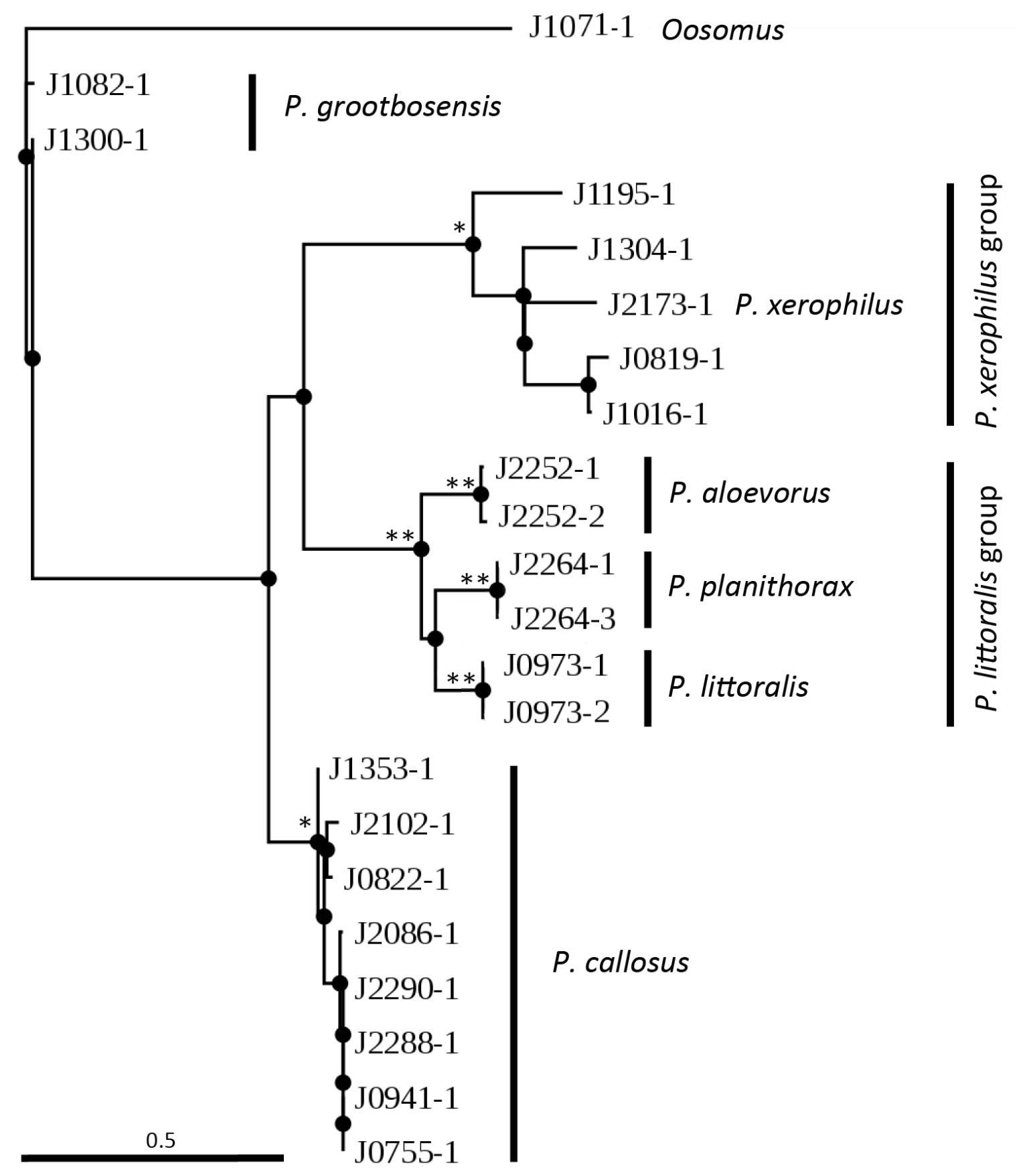

Fig. 5. PhyML tree of Phlyctinus Schoenherr, 1826 species inferred from mitochondrial Cytochrome oxidase I (COI, 658 base pairs). Bootstrap support values as obtained from 1000 replicates (*above 80, ** above 95). Specimens codes were shortened for representation: JHAR0 $=\mathrm{J}$ and $\_0101=-1$. 


\section{Remarks}

Phlyctinus aloevorus sp. nov. belongs to the P. littoralis sp. nov. species group, in which it is closest to P. planithorax sp. nov. (see discussion under that species for distinguishing characters). It can easily be distinguished from specimens of $P$. littoralis sp. nov. by the presence of a distinct median carina on the prothorax. Both species show an uncorrected p-distance of 5.3\%.

\section{Key to species of Phlyctinus}

1. Ventrites 1 and 5 of male with erect golden setae forming two circular tufts (Fig. 3B); cavity of ventrite 5 extending over apical $4 / 5$ of length, ventrites $2-4$ with elongate tubercles at base of scales; external margin of eyes round, surface slightly conical in dorsal view (Fig. 1B). On Asteraceae in coastal habitats Phlyctinus grootbosensis sp. nov.

- Ventrites 1 and 5 of male with setae more or less erect but not forming dense tufts (Fig. 3A, C), cavity of ventrite 5 extending only over apical $2 / 3$ of length, integument of ventrites $2-4$ smooth, lacking elongate tubercles at base of scales; external margin of eyes rounded, surface slightly conical or strongly conical in dorsal view (Fig. 1A, E)

2. Cavity of ventrite 5 of male with erect setae along whole length of median area (Fig. 3C); body length $>7 \mathrm{~mm}$; elytra of female with large tubercles and usually a contrasting transverse pale band on declivity (Fig. 1C); scales on prothorax dense, concealing integument, leaving only tubercles at base of setae and median carina visible; body of penis short, $0.5 \times$ as long as apodemes; endophallus with a sclerotised plate forming a square angle below base of body of penis (Fig. 2C). Polyphagous, in inland valleys of Worcester region

Phlyctinus xerophilus sp. nov.

- Cavity of ventrite 5 of male lacking erect setae in middle, or only present in basal half (Fig. 3A, D); body length $<7 \mathrm{~mm}$; elytra of female with no or only small tubercles and transverse, pale, contrasting or indistinct band on declivity (Fig. 1A, D-F); scales on prothorax usually scattered, not concealing integument between tubercles and punctures; body of penis longer, more than $0.6 \times$ as long as apodemes; endophallus lacking sclerotised plate (Fig. 2A, D-F) ....................................... 3

3. Scales on elytra always consisting of a mixture of wide and very narrow, hair-like ones (Fig. $3 \mathrm{E}$ ); elytral declivity always with small but distinct tubercles on interstriae 3-5-7; eyes strongly protruding, surface conical in dorsal view (Fig. 1A); prothorax with 2 slight cuticular depressions on each side of median line; in female, transverse band of elytra generally extending over all interstriae. Polyphagous, widespread across the Western Cape province and introduced overseas

Phlyctinus callosus (Schoenherr, 1826)

- Scales of elytra only elliptical in $95 \%$ of specimens (Fig. 3F); elytra with tubercles on declivity absent or very reduced on interstriae 3-5-7; eyes very protruding, with a conical surface, or not, in dorsal view (Fig. 1D-F); prothorax regularly convex, without cuticular depression; in female transverse band of elytra generally reduced to interstriae 1-3 (Fig. 1D, F) or lacking (Fig. 1E). Coastal habitats of the Kogelberg Nature Reserve

4. Body integument covered with homogeneous greyish scales, a few paler spots scattered on elytra (Fig. 1E); eye margin round in dorsal view, or angled (Fig. 1E); body of penis widest near base, sides almost straight, converging apicad (Fig. 2E) Phlyctinus littoralis sp. nov.

- Body integument covered with brown, black or pearly green scales forming more or less contrasting patterns (Fig. 1D, F); eyes protruding, surface distinctly conical in dorsal view (Fig. 1D, F); body of penis with sides convex, widest near basal $1 / 3$ or near middle of length (Fig. 2D, F)

5. Integument of prothorax with a smooth, shiny and very distinct carina in middle of length; vestiture of elytra forming a few ill-defined paler spots in addition to transverse band, this not always visible 
(Fig. 1F); erect scales on ventrites 1-4 shorter than claws; copulatory sclerite with setae at base of left arm (Fig. 2F) Phlyctinus aloevorus sp. nov.

- Integument of prothorax densely punctate, lacking longitudinal carina; vestiture of elytra with contrasting scattered pale spots in addition to transverse band (Fig. 1D); erect scales on ventrites 1-4 longer than claws; copulatory sclerite lacking setae at base of left arm (Fig. 2D)

Phlyctinus planithorax sp. nov.

\section{Discussion}

This study showed that the genus Phlyctinus is not monotypic but contains several closely related species. The examination of morphological features and the preliminary phylogenetic analysis based on $C O I$ sequences allowed the recognition of six species, five of them being described here as new. Four species groups were identified; the P. callosus, P. grootbosensis sp. nov., P. xerophilus sp. nov. and $P$. littoralis sp. nov. groups. The $P$. littoralis sp. nov. group comprises three closely related species inhabiting the southern coast of the Western Cape province. The P. xerophilus sp. nov. group contains several mitochondrial lineages that may represent several cryptic species. This group is found mostly in the inland area of the province and requires verification. This study highlighted the importance of conducting detailed integrative taxonomic studies for economic pests.

From an applied perspective, two of the species of this genus are currently treated as pests in orchards and vineyards, P. callosus and P. xerophilus sp. nov. Although morphologically similar, they can readily be distinguished by their size and by the different arrangements of erect setae on ventrite 5 of the males. As Phlyctinus species are often transported by humans, determining the natural range of the species is challenging. However, the samples obtained in the course of this study suggest that $P$. xerophilus sp. nov. has a narrower range than P. callosus, being restricted to inland valleys of the Worcester region. More detailed research is needed to determine their exact distribution ranges, host plants and climatic niches, because they could have been confused in previous studies (Barnes 1989). Identifying the host range of $P$. xerophilus sp. nov. and of Phlyctinus species in general is critical in the context of the growing use of cover crops in orchards and vineyards (Schipanski et al. 2014; Thierfelder et al. 2018). The host records listed in this study suggest that the genus Phlyctinus is mainly associated with Asteraceae growing in wet and naturally disturbed coastal and riparian habitats. The apparent preference of Phlyctinus for these habitats probably explains its harmfulness in fields of irrigated crops.

\section{Acknowledgements}

We wish to thank Max Barclay (BMNH), Simon van Noort (SAMC), Elisabeth Grobbelaar, Riaan Stals (SANC), Johannes Bergsten (NHRS), Meshack Magagula (Stellenbosch University) and Dominique Menet (France) for providing the specimens or images that made this study possible. We thank the Western Cape Nature Conservation Board (permit No. CN44-30-4229) and the Cape Research Centre (South African National Parks, CRC/2019-2020/012-2012/V1) for authorization to collect specimens in the Western Cape province. We acknowledge Paula Strauss, Gary Beukman and Michael Lutzeyer for access to the Grootbos Private Nature reserve, their friendly assistance during sampling and for their support for the achievement of this study. We thank Stuart Hall (Stellenbosch) for his help with identifying host plants, and Roman Borovec (Czech Republic) and Jean Pelletier (France) for help with the morphological treatment of new species and the literature review on Phlyctinus. We acknowledge two anonymous reviewers for constructive comments on the manuscript and Peter Biggins (CIRAD), who revised the English. 


\section{References}

Alonso-Zarazaga M.A. \& Lyal C.H.C. 1999. A World Catalogue of Families and Genera of Curculionoidea (Insecta: Coleoptera) (Excepting Scolytidae and Platypodidae). Entomopraxis, Barcelona.

Anonymous 1950. List of Intercepted Plant Pests, 1948. United States Department of Agriculture, Bureau of Entomology and Plant Quarantine, Service and regulatory announcements.

Barnes B.N. 1989. Different life and seasonal cycles of Banded Fruit Weevil, Phlyctinus callosus (Coleoptera: Curculionidae), in apple orchards in the south-western Cape. Phytophylactica 21 (2): 147157.

Barnes B.N. \& Pringle K.L. 1988. Sensitivity to cypermethrin of two strains of vine snoutbeetle, Phlyctinus callosus, from apple orchards. Phytophylactica 20: 91-92.

Borovec R. 2019. Three new South African Embrithini (Coleoptera, Curculionidae, Entiminae). Zootaxa 4555 (2): 259-267. https://doi.org/10.11646/zootaxa.4555.2.6

Borovec R. \& Skuhrovec J. 2018. Afromuelleria, a new genus of Trachyphloeini from Limpopo, with descriptions of four new species (Coleoptera: Curculionidae: Entiminae). European Journal of Entomology 115: 668-683. https://doi.org/10.14411/eje.2018.066

Bouchenak-Khelladi Y. \& Linder H.P 2017. Frequent and parallel habitat transitions as driver of unbounded radiations in the Cape flora. Evolution 71 (11): 2548-2561. https://doi.org/10.1111/evo.13364

Broun T. 1893. Descriptions of new Coleoptera from New Zealand (continued). Annals and Magazine of Natural History, Series 6, 12 (71): 374-392. https://doi.org/10.1080/00222939308677637

Brown E.B. 2004. Phlyctinus callosus Boheman 1834 (Curculionidae, Otiorhynchini) - recorded in Great Britain. The Coleopterist 13 (4): 160.

Decelle J. \& Voss E. 1972. La faune terrestre de l'île de Sainte-Helène (deuxième Partie). II. Insecta 9. Coleoptera. 35, Fam Curculionidae. Annales du Musée Royal de l'Afrique Centrale, Tervuren, Sciences Zoologiques 192: 306-515.

Duff A.G. 2012. Checklist of Beetles of the British Isles. Revised Edition. Pemberley Books, Iver, United Kingdom.

Ellis A.G., Verboom G.A., Van Der Niet T., Johnson S.D. \& Linder H.P. 2014. Speciation and extinction in the Greater Cape Floristic Region. In: Verboom G.A., Bergh N.G. \& Colville J.F. (eds) Fynbos: Ecology, Evolution, and Conservation of a Megadiverse Region: 119-141. Oxford University Press. https://doi.org/10.1093/acprof:oso/9780199679584.003.0006

Folmer O., Black M., Hoeh W., Lutz R. \& Vrijenhoek R. 1994. DNA primers for amplification of mitochondrial cytochrome c oxidase subunit I from diverse metazoan invertebrates. Molecular Marine Biology and Biotechnology 3 (5): 294-299.

Germain J.-F., Chatot C., Meusnier I., Artige E., Rasplus J.-Y. \& Cruaud A. 2013. Molecular identification of Epitrix potato flea beetles (Coleoptera: Chrysomelidae) in Europe and North America. Bulletin of Entomological Research 103: 354-362. https://doi.org/10.1017/S000748531200079X

Guindon S. \& Gascuel O. 2003. A simple, fast, and accurate algorithm to estimate large phylogenies by maximum likelihood. Systematic Biology 52 (5): 696-704. https://doi.org/10.1080/10635150390235520

Haran J., Koutroumpa F., Magnoux E., Roques A. \& Roux G. 2015. Ghost mtDNA haplotypes generated by fortuitous NUMTs can deeply disturb infra-specific genetic diversity and phylogeographic pattern. Journal of Zoological Systematics and Evolutionary Research 53: 109-115. https://doi.org/10.1111/jzs.12095 
Hebert P.D., Cywinska A., Ball S.L. \& deWaard J.R. 2003. Biological identifications through DNA barcodes. Proceedings of the Royal Society B, Biological Sciences 270 (1512): 13-21.

https://doi.org/10.1098/rspb.2002.2218

Hoffmann V., Verboom G.A. \& Cotterill F.P.D. 2015. Dated plant phylogenies resolve Neogene climate and landscape evolution in the Cape Floristic Region. PLoS ONE 10 (9): e 0137847.

https://doi.org/10.1371/journal.pone.0137847

Ivanova N.V., Zemlak T.S., Hanner R.H. \& Hebert P.D.N. 2007. Universal primer cocktails for fish DNA barcoding. Molecular Ecology Notes 7: 544-548. https://doi.org/10.1111/j.1471-8286.2007.01748.x

Kumar S., Stecher G. \& Tamura K. 2016. MEGA7: Molecular Evolutionary Genetics Analysis version 7.0 for bigger datasets. Molecular Biology and Evolution 33: 1870-1874.

https://doi.org/10.1093/molbev/msw054

Lacordaire T. 1854. Histoire naturelle des Insectes. Genera des Coléoptères, ou exposé méthodique et critique de tous les Genres proposés jusqu'ici dans cet Ordre d'Insectes. Tome Premier. [Completed by J. Chapuis.] Librairie encyclopédique de Roret, Paris, France. https://doi.org/10.5962/bhl.title.8864

Linder H.P. 2003. The radiation of the Cape flora, southern Africa. Biological Reviews 78: 597-638. https://doi.org/10.1017/S1464793103006171

Lona C. 1937. Curculionidae: Otiorrhynchinae II. In: Coleopterorum Catalogus auspiciis et auxilio W. Junk editus a S. Schenkling, Pars 162: 227-412. Junk, Berlin.

Lyal C.H.C. 2019. Glossary of weevil characters. International Weevil Community. Available from http://weevil.info/glossary-weevil-characters [accessed 20 Jun. 2019].

Marshall G.A.K. 1926. Some new Curculionidae from New Zealand (Col). Annals and Magazine of Natural History, Series 9, 18 (103): 1-16. https://doi.org/10.1080/00222932608633472

Marshall G.A.K. 1926. Some new Curculionidae from New Zealand (Col). Annals and Magazine of Natural History, Series 9, 18 (103): 1-16. https://doi.org/10.1080/00222932608633472

Marshall G.A.K. 1927. New injurious Curculionidae (Col.). Bulletin of Entomological Research 7 (3): 199-218.

Marshall G.A.K. 1952. XXVIII. - Taxonomic notes on Curculionidae (Col.). Annals and Magazine of Natural History, Series 12, 5 (51): 261-270. https://doi.org/10.1080/00222935208654289

Myburgh A.C. \& Kriegler P.J. 1967. Experiments on sterilization of the snout beetles, Phlyctinus callosus Boh. and Eremnus setulosus Boh. on export grapes in cold-storage. Journal of the Entomological Society of Southern Africa 29: 96-101.

Oberprieler R.G., Marvaldi A.E. \& Anderson R.S. 2007. Weevils, weevils, weevils everywhere. Zootaxa 1668 (1): 491-520. https://doi.org/10.11646/zootaxa.1668.1.24

Olliff A.S. 1888. IV. Insecta. In: Millington, J.A.M. (ed.) Report on a small zoological collection from Norfolk Island. Proceedings of the Linnean Society of New South Wales, Series 2, 2: 1001-1014. https://doi.org/10.5962/bhl.part.29223

Opatowski D. 2001. EPPO Panel on Pest Risk Analysis. Bulletin OEPP 31 (3): 371-374.

Poussereau J., Voisin J.F., Lemagnen R. \& Menet D. 2013. Découverte de Phlyctinus callosus et Dorymerus sulcatus à La Réunion (Coleoptera, Curculionidae, Entiminae). Le Coléoptériste 16: 121-123.

Pringle K.L., Barnes T.L. \& Blomefield T.L. 2015. Apple. In: Prinsloo G.L. \& Uys V.M. (eds) Insects of Cultivated Plants and Natural Pastures in Southern Africa: 350-365. The Entomological Society of Southern Africa, Hatfield, South Africa. 
Prinsloo G.L. \& Uys V.M. 2015. Insects of Cultivated Plants and Natural Pastures in Southern Africa. The Entomological Society of Southern Africa, Hatfield.

Procheş Ş. \& Cowling R.M. 2006. Insect diversity in Cape fynbos and neighbouring South African vegetation. Global Ecology and Biogeography 15: 445-451.

https://doi.org/10.1111/j.1466-822X.2006.00239.x

Procheş Ş., Forest F., Veldtman R., Chown S.L., Cowling R.M., Johnson S.D., Richardson D.M. \& Savolainen V. 2009. Dissecting the plant-insect diversity relationship in the Cape. Molecular Phylogenetics and Evolution 51: 94-99. https://doi.org/10.1016/j.ympev.2008.05.040

Pullen K.R., Jennings D. \& Oberprieler R.G. 2014. Annotated catalogue of Australian weevils (Coleoptera: Curculionoidea). Zootaxa 3896 (1): 1-481. https://doi.org/10.11646/zootaxa.3896.1.1

Schipanski M.E., Barbercheck M., Douglas M.R., Finney D.M., Haider K., Kaye J.P., Kemanian A.R., Mortensen D.A., Ryan M.R., Tooker J. \& White C. 2014. A framework for evaluating ecosystem services provided by cover crops in agroecosystems. Agricultural System 125: 12-22.

https:// doi.org/10.1016/j.agsy.2013.11.004

Schoenherr C.J. 1826. Curculionidum Dispositio Methodica, cum Generum Characteribus, Descriptionibus atque Observationibus variis, seu Prodromus ad Synonymiae Insectorum, Partem IV. Fleischer, Leipzig [Lipsiae]. https://doi.org/10.5962/bhl.title.9327

Schoenherr C.J. 1834. Genera et Species Curculionidum, cum Synonymia hujus Familiae; Species novae aut hactenus minus cognitae, Descriptionibus a Dom. Leonardo Gyllenhal, C. H. Boheman, et Entomologis aliis illustratae. Tomus secundus. Pars prima. Roret, Paris [Parisiis].

Schoenherr C.J. 1843. Genera et species Curculionidum, cum synonymia hujus familiae; species novae aut hactenus minus cognitae, descriptionibus a Dom. Leonardo Gyllenhal, C. H. Boheman, et entomologis aliis illustratae. Tomus septimus. Pars secunda. Roret, Paris [Parisiis].

Thierfelder C., Baudron F., Setimela P., Nyagumbo I., Mupangwa W., Mhlanga B., Lee N. \& Gérard B. 2018. Complementary practices supporting conservation agriculture in Southern Africa. A review. Agronomy for Sustainable Development 38 (16): 1-22. https://doi.org/10.1007/s13593-018-0492-8

Wollaston T.V. 1869. On the Coleoptera of St. Helena. Annals and Magazine of Natural History, Series 4, 4: 19-24. https://doi.org/10.1080/00222936908696087

Manuscript received: 15 August 2019

Manuscript accepted: 23 April 2020

Published on: 18 June 2020

Topic editor: Gavin Broad

Section editor: Max Barclay

Desk editor: Pepe Fernández

Printed versions of all papers are also deposited in the libraries of the institutes that are members of the EJT consortium: Muséum national d'histoire naturelle, Paris, France; Meise Botanic Garden, Belgium; Royal Museum for Central Africa, Tervuren, Belgium; Royal Belgian Institute of Natural Sciences, Brussels, Belgium; Natural History Museum of Denmark, Copenhagen, Denmark; Naturalis Biodiversity Center, Leiden, the Netherlands; Museo Nacional de Ciencias Naturales-CSIC, Madrid, Spain; Real Jardín Botánico de Madrid CSIC, Spain; Zoological Research Museum Alexander Koenig, Bonn, Germany; National Museum, Prague, Czech Republic. 
HARAN J.M. et al., New species of the genus Phlyctinus Schoenherr

Appendix 1. PCR primers and conditions. M13 tails from Ivanova et al. (2007) are highlighted.

\begin{tabular}{|c|c|c|c|}
\hline Gene & Primer & & Reference \\
\hline \multirow{6}{*}{ COI } & \multirow{3}{*}{ HCO2198 } & CAGGAAACAGCTATGACTAAACYTCDGGATGBCCAAARAATCA & \multirow{3}{*}{$\begin{array}{l}\text { Folmer et al. (1994), } \\
\text { modified in Germain } \\
\text { et al. }(2013)\end{array}$} \\
\hline & & CAGGAAACAGCTATGACTAAACYTCAGGATGACCAAAAAAYCA & \\
\hline & & CAGGAAACAGCTATGACTAAACTTCWGGRTGWCCAAARAATCA & \\
\hline & \multirow{3}{*}{ LCO1490 } & TGTAAAACGACGGCCAGTTTTCAACTAAYCATAARGATATYGG & \\
\hline & & & \\
\hline & & TGTAAAACGACGGCCAGTTTTCAACWAATCATAAAGATATTGG & \\
\hline
\end{tabular}

